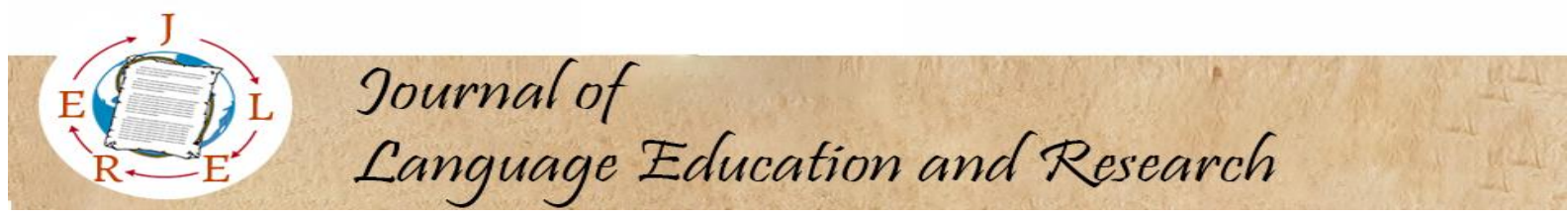

$7(1), 2021$

\author{
Journal of Language Education and Research
}

\author{
Research Article
}

\title{
Conducting and Evaluating Reading Development Studies on a Student with Fluency Reading Problems
}

\author{
Cengiz Kesik *
}

\author{
Meliha Efe Kesik $^{* *}$
}

\section{ARTICLE INFO}

Received 17.03.2021

Revised form 02.04.2021

Accepted 20.04.2021

Doi: $10.31464 /$ jlere. 898499

Keywords:

Fluent reading

Word recognition

Reading speed

Reading comprehension

Prosody

\begin{abstract}
This study aimed to determine the effect of more than one fluent reading method and technique (repetitive reading, mumble reading, rhyming reading, reading aloud, and widening the visual spectrum) to overcome the fluent reading problem. In line with the research's purpose, the single-subject research method, one of the quantitative research methods, was used. In the study in which the criterion sampling method, one of the purposeful sampling methods, was used, a study was conducted with a fifth-grade student who was found to have a fluent reading problem. The research was carried out to do fluent reading studies for 15 lesson hours with fluent reading methods and techniques determined in the school library at one-day intervals during one lesson. The data of the research were analyzed with descriptive statistics. Although there was a mathematical improvement in the word recognition level and reading comprehension level of the student studied in the study, the student could not reach the free level and remained at the level of anxiety. The study concluded that more than one fluent reading method and technique used to solve the fluent reading problem was effective in providing mathematical progress in the student's reading speed, word recognition percentage, and prosody and in reducing some reading errors observed in the student.
\end{abstract}

Acknowledgments

Statement of Publication Ethics

Authors' Contribution Rate

Conflict of Interest
The study was conducted in accordance with the ethical committees.

Each author's contribution rate to the article is $50 \%$.

There is no conflict of interest between the authors.

\footnotetext{
* Research Assistant, ORCID ID: https://orcid.org/0000-0001-9777-0076, Harran University, Department of Elementary Education, cengiz_kesik@hotmail.com ** Primary School Teacher, ORCID ID: https://orcid.org/0000-0002-5882-2475, Ministry of Education, melihaaa_93@live.de
} 


\section{Introduction}

Various definitions and explanations about reading have been carried out from past to present. In the past, "reading" was understood as deciphering texts, and the emphasis was placed on reading aloud. Reading, which is later on explained as seeing the words as a whole and placing them in mind, is now considered developing language and mental skills. Reading is a process in which prior information and information in the text are integrated and reinterpreted. This process consists of various operations of our eyes, sound, and brain, such as seeing, vocalizing, understanding, and mental structuring. It starts with the perception of lines, letters, or symbols first, then the attention is concentrated, and the meaning of words and sentences is found (Güneş, 2017). However, some students cannot fully fulfill these skills and therefore cannot read fluently. The reasons for these students to read slowly can be listed as follows (Akyol, 2011): syllable based reading, slow word recognition, word-by-word reading, whispering reading, lip movements, silent (inner) speech, finger tracking, head movements, returning during reading, and transition from line to line.

Studies are carried out according to certain stages, methods, and techniques to prevent the stated reasons for slow reading and develop fluent reading skills in children. These methods and techniques can be sorted as; reading aloud, silent reading, speed reading, guided reading, full reading, intertextual reading, reading by discussing, glance reading, reading by note-taking, underline reading, elective reading, reading drama, word choir, reading by asking questions, reading by guessing, reading by summarizing, reading by memorizing, critical reading, poetry reading, visual reading, reading skipping, screen reading, alternating reading, repeated reading, paired reading, choral reading, mumble reading, reading with friends, cooperative repetitive reading, radio reading, echo reading, rhythmic reading with symmetrical letters, rhyming reading, expanding the visual spectrum, performance reading and recording reading (Duran and Bitir, 2020; Güneş, 2017). The listed reading methods and techniques are applied according to certain stages. These stages are; the pre-reading stage in which reading preparation and reading planning studies are carried out; the reading stage in which the correct pronunciation of words, understanding of sentences, paragraphs, and texts, structuring the information in mind and its practice is done; is the post-reading phase in which studies to evaluate, question, criticize and interpret the information conveyed in the text (Güneş, 2017).

\section{Literature review}

When the literature on reading education is examined, it is seen that studies are conducted with children at different grade levels according to different reading stages, methods, and techniques. Sağlam, Baş, and Akyol (2020), in their study with third-grade children with special talents, stated that the word repetition technique removes reading aloud errors and is beneficial in developing their fluent reading and reading comprehension skills. Also, they stated that there is an increase in the rate of paying attention to stress and intonation, and hesitation while reading. Erbasan and Sağlam (2020) explain that guided reading technique has positive effects on developing fluent reading and reading comprehension skills of homeschooling students with dyslexia. Akyol and Sever 
(2019), in their practices, used the Fernald method, echo, and repetitive reading strategies, for an elementary school sophomore with reading and writing disabilities. They stated that the student could read 30 words of a text that he could not read before the practice, made 8 reading errors during reading, increased his desire to read, began to read aloud, noticed what he read and that his writing's legibility level reached a medium level. Kuruoğlu and Şen (2019) emphasize that accelerated reading education applied to secondary school students who have reading disabilities significantly increases the reading speed and reading aloud levels of students. Kanık Uysal and Akyol (2019) prepared an action plan that includes repetitive, model, assisted, echo, and choral reading models for solving the reading and comprehension problems of a seventh-grade student with reading disabilities. They stated that the student's reading level after the practices reached an instructional level from anxiety level. Karasakaloğlu and Saraçlı Çelik (2018) state that the guided reading method contributes to the development of reading, reading and listening comprehension skills of primary school third-grade students who have reading disabilities. Besides, they stated that working one-on-one with children and guiding them led to a noticeable improvement in improving children's writing, improving their ability to answer questions, and using punctuation marks correctly. Akyol and Ketenoğlu Kayabaş1 (2018) stated that they focused on sounds, syllables and words for 15 hours in the reading difficulty program they prepared for a student with reading disabilities, and they focused on reading fluency with paired reading and repetitive reading method for 15 hours. Moreover, they state that thanks to this program, the student's reading and comprehension level increased from anxiety level to the level of teaching. Sözen and Akyol (2018) also stated in their study with the guided reading method that the guided reading method contributed to eliminating reading disabilities and developing comprehension skills of third-grade primary school students with reading disabilities. Çayır and Balcı (2017) prepared and implemented a reading program consisting of echo reading, repetitive reading, and certain reading strategies for an elementary school third-grade student with reading disability and stated that at the end of the practice, the reading disabilities experienced by the student decreased significantly, but the desired level of reading fluency was not reached. Akyol and Kodan (2016) prepared a 45-hour reading program in which repetitive, paired, echo, and independent reading strategies were applied for a primary school fourth-grade student with reading disabilities. It was observed that the student's reading and comprehension levels improved after the implementation. Kardaş İşler and Şahin (2016) conducted practices based on the strategy of listening to the paragraph beforehand and paired reading strategy with a primary school fourth-grade student who had reading disabilities and observed that the student's reading and reading comprehension problems decreased at the end of the practice. Çeliktürk Sezgin and Akyol (2015) explain that the student's word recognition and comprehension level increased from anxiety level to education level in the practice they performed using repetitive reading, paired reading, and reader's theater techniques to improve the reading skills of a fourth-grade student with reading disabilities. Yamaç (2014) applied repetitive reading, paired reading, and word-building techniques to improve a fourth-grade student's reading fluency who had reading disabilities. And at the end of the practice, he states that the student's word recognition skill increased from anxiety level to free level, his reading speed increased from 20.8 to 34.2 per minute, and his prosody score 
increased from $15 \%$ to $66 \%$. Duran and Sezgin (2012), in a study examining the effect of the guided reading method on primary school students '(1-4th grades) fluent reading, state that guided reading method reduced elementary school students' reading aloud errors, increased word recognition, and comprehension levels, and that aloud reading skills increased from anxiety level to teaching level. Sidekli and Yangin (2005) applied multisensory approaches to their fifth students who had reading disabilities and stated that the student's reading level improved from anxiety level to instructional level at the end of the practices. Gürkaner and Güven (2020), on the other hand, in the studies conducted between 2012-2018 on the subject postgraduate thesis built on fluent reading at the elementary school level in Turkey, in the postgraduate theses performed between these years, fluent reading strategies, methods, and techniques of the paired reading, choral reading, structured reading, repeated reading, SQ3R, the six-minute method, resonant reading, reading drama and reading by sharing was found to be used. In the results of postgraduate theses based on these strategies, methods, and techniques, there were positive developments in children's reading speed, correct reading skills, prosodic reading skills, reading comprehension, academic achievement, and reading motivation. These findings indicates that studies on fluent reading have been conducted with different purposes and methods.

Regardless of the strategy, method, and technique used in the development of fluent reading skills, what is important in this regard is the interest of the classroom teacher and sparing time for students with fluent reading problems. When the literature on fluent reading is examined, it is seen that programs are prepared, and practices are made based on different reading methods, techniques, and strategies to solve the fluent reading problem(Sağlam, Baş ve Akyol, 2020; Erbasan and Sağlam, 2020; Akyol and Sever, 2019; Kuruoğlu and Şen, 2019; Kanık Uysal and Akyol, 2019; Karasakaloğlu and Saraçlı Çelik, 2018; Akyol and Ketenoğlu Kayabaş1, 2018; Sözen and Akyol, 2018; Çayır and Balc1, 2017; Akyol and Kodan, 2016; Kardaş İşler and Şahin, 2016; Çeliktürk Sezgin and Akyol, 2015; Yamaç, 2014; Duran and Sezgin, 2012; Sidekli and Yangın, 2005). In this study, distinct from the reading methods, techniques, and strategies applied in the relevant literature, the methods and techniques based on repetitive reading, mumble reading, rhyming reading, reading aloud, and widening the vision spectrum were used. The practices based on these methods and techniques are considered important in terms of being an example for fluent reading studies. Voice reading is the voice of the words and word groups that the individual sees and grasps in his mind (Ünalan, 2006; Duran and Bitir, 2020). The main purpose of reading aloud is to enable the individual to pronounce the words correctly and read them by considering the meaning of these words (Özbay, 2007). Repetitive reading is the repeated reading of a short text to an individual who has disabilities reading until they reach fluent reading (Samules, 1997). These repetitions are done under the guidance of an adult. The texts are read from easy to difficult. This method aims to increase the speed of word recognition and allow them to spend more time understanding. Rhymed reading is the resemblance of the sounds at the end of rhyme lines in terms of structure. Rhyming reading is, on the other hand, reading poems made up of rhymed lines. Rhyming reading can improve individuals' reading by having fun, sound 
awareness, and fluent reading skills. These are the studies in which activities based on reading texts consisting of different geometric shapes are applied to expand the spectrum of vision and teach individuals with reading disabilities to read rapidly (Güneş, 2015). On the other hand, mumble reading is a reading made in a little and low voice based on certain lip movements. It was aimed to test the reading speed, word recognition level, and reading comprehension of the student using repetitive reading, mumble reading, rhyming reading, reading aloud, and expanding the visual spectrum. From this point of view, it is aimed to use more than one fluent reading method and technique in solving a student's fluent reading problem. For this purpose, answers were sought for the following problems and sub-problems.

\section{Problem statement of the study}

Is there any effect of using more than one fluent reading method and technique (repetitive reading, mumble reading, rhyming reading, reading aloud, and expanding the vision spectrum) in solving the fluent reading problem?

\section{Sub problems}

The use of more than one fluent reading method and technique to solve the fluent reading problem:

a. Does it affect reading speed, word recognition percentage, and prosody?

b. Does it affect the word recognition level?

c. Does it affect the level of reading comprehension?

\section{Methodology}

\section{Research design and publication ethics}

In line with the research's purpose, the single-subject research method, one of the quantitative research methods, was used in the study. In some special cases, the number of individuals in the population where experimental studies will be conducted may be small. For example, an experiment to be carried out in studies to be carried out with individuals requiring special education can be developed specifically for a single individual (Büyüköztürk, Kılıç Çakmak, Akgün, Karadeniz \& Demirel, 2018: 18). In this context, the research was conducted with a student who has a fluent reading problem. This article adheres to research and publication ethics.

\section{Context}

This study was carried out in a secondary school in the 2018-2019 academic year.

\section{Participants}

Criterion sampling, one of the purposeful sampling methods, was used to determine the student in the study group of the study. Criterion sampling is that the observation units in research consist of people, events, objects, or situations with certain qualities (Büyüköztürk et al., 2018, p.91). The student in the study group is a student who has a fluent reading problem in the fifth grade of an official secondary school affiliated to the 
Ministry of National Education in the 2018-2019 academic year and is behind his/her friends and grade level in reading. Some demographic information about the student is explained in Table 1.

Table 1. Demographic Information of the Student Participating in the Study

$\begin{array}{ll}\text { Gender } & \text { Male } \\ \text { Grade Level } & 5 \\ \text { Father's educational status } & \text { Primary school } \\ \text { Father's Occupation } & \text { Unemployed } \\ \text { Mother's educational level } & \text { Primary school } \\ \text { Mother's Occupation } & \text { Housewife } \\ \text { Number of Siblings } & 3 \\ \text { Socioeconomic status } & \text { Low }\end{array}$

As seen in Table 1, the student participating in the study is in the 5th grade. In the process of determining the student, the teachers who attended the course were interviewed, and information about the student's in-class performance, academic success, and general situation were obtained. This student does not have any learning disabilities and only has a fluent reading problem. The student comes from a family with a low socioeconomic level, his father is not working, and his mother is a housewife. The student is the thirdborn in the family. The student has no permanent illness and uses no medication. During the student's 4-year primary school education process, 3 different classroom teachers have attended his/her class. In other words, a different classroom teacher attended his/her every year.

\section{Data collection and analysis}

\section{Incorrect analysis inventory}

This inventory was developed by Ekwall and Shanker (1988) and adapted by Akyol (2003). Environment and vocalization scale (determining word and phonetic knowledge with mistakes made during reading aloud, and comprehension skill and level with questions asked after reading the text silently), word recognition percentage (The percentage of words that the student reads correctly during 60 seconds of reading aloud is determined by calculating. This percentage is determined by dividing the number of correctly read words by the total number of words read.) and consists of reading speed (the number of words that the student reads correctly in a 60 -second reading period).

\section{Reading prosody rubric}

It was developed by Zutell and Rasinski (1991) and adapted to Turkish by Yıldırım, Yıldız and Ateş (2009). It consists of 4 dimensions: expression and sound level, units of meaning, intonation, smoothness, and speed. As a result of the reading practices, the student must get a score of at least 8 and above from this rubric. A student with a score below 8 needs additional practices. 


\section{Rubric for evaluating reading comprehension by expressing reading}

Developed by Rasinski and Padak (2005), adapted to Turkish by Akyol, Rasinski, Yıldırım, Ateş, and Çetinkaya (2014). As a result of the reading practices, the student is required to get scores between 4-6 points from this rubric. If the student's score is 3 or less than 3 , the student needs additional practices.

\section{Procedure}

\section{Pre-practice phase}

At this stage, the student was given a text called "The Excitement Is at its Peak," consisting of 121 words at the 4th-grade level. This text is taken from the Turkish textbook of the 4th grade of the Ministry of National Education. Voice recording was taken while the student was reading the text. This voice recording was analyzed according to the following data collection tools, and the current reading level of the student was determined. These data collection tools are Environment and Speaking Scale, Word Recognition Percentage, Reading Speed, Reading Prosody Rubric, and Reading Comprehension Assessment Rubric by Explaining Reading.

\section{Fluent Reading Studies}

After determining the student's current reading level, a reading program was prepared by the researchers to be applied to the student. This reading program has been selected by considering different fluent reading methods and techniques in the literature. These fluent reading methods and techniques; repetitive reading, mumble reading, rhyming reading, reading aloud, and expanding the visual spectrum [GYP]. One of the researchers applied the prepared reading program for 15 lesson hours at the determined hours in the school library. Each lesson lasted 40 minutes. The texts taught within the scope of the reading program were taken from Coşkun and Çeçen's (2012) book "Hızlı ve Anlayarak Okuma Tekniği". Table 2 describes which text was taught at what time of the reading program and which reading method and technique was used.

Table 2. Fluent Reading Studies

\begin{tabular}{|c|c|c|}
\hline Practice Time & Text & Reading Method and Technique \\
\hline 1. Time & Cat & Rhyming, Loud and Repetitive Reading \\
\hline 2. Time & Artichoke & Loud and Repetitive Reading \\
\hline 3. Time & Autumn came & Loud and Repetitive Reading \\
\hline 4. Time & Nasreddin Hodja & Rhyming, Loud and Repetitive Reading \\
\hline 5. Time & My Teacher & Rhyming, Loud and Repetitive Reading \\
\hline 6. Time & Zeki Run & GYP, Loud and Repetitive Reading \\
\hline 7. Time & Engin Wake up & GYP, Loud and Repetitive Reading \\
\hline 8. Time & The Ant and the Pigeon & GYP, Loud and Repetitive Reading \\
\hline 9. Time & Mother's Heart & GYP, Loud and Repetitive Reading \\
\hline 10. Time & Last Regret & GYP, Loud and Repetitive Reading \\
\hline 11. Time & Atatürk Had A Watch & Rhyming, Loud and Repetitive Reading \\
\hline 12. Time & The Fighter Lion and The Boar & Mumbling, Loud and Repetitive Reading \\
\hline 13. Time & The Snail and Its House & Mumbling, Loud and Repetitive Reading \\
\hline 14. Time & Oh My God Look at The Plan & Mumbling, Loud and Repetitive Reading \\
\hline 15. Time & Good versus Evil & Mumbling, Loud and Repetitive Reading \\
\hline
\end{tabular}




\section{Final practice phase}

After the fluent reading studies were completed, in order to determine the status of the student, the student was re-read the text "Excitement at Its Peak" and after that, a text called "Marbling Art" consisting of 165 words was also taught at his own grade level. The text titled "Marbling Art" is taken from the book titled "Okumay1 Değerlendirme" by Akyol, Yıldırım, Ateş, Çetinkaya and Rasınskı (2014). The reason why the student was taught two different texts in the final implementation is to see what level s/he reached in the text below his/her grade level (4th grade) in the pre-practice and what level s/he reached in the text at his/her own grade (5th grade). Since the student had a fluent reading problem according to his/her grade level, the pre-practice was only taught a single text at the 4th-grade level. Voice recording was taken while the student was reading the texts. This voice recording was analyzed according to the following data collection tools, and it was determined how much the student made progress. These data collection tools are Environment and Speaking Scale (Ekwall and Shanker), Word Recognition Percentage, Reading Speed, Reading Prosody Rubric, and Reading Comprehension Assessment Rubric by Narrating Reading.

\section{Results}

In this section, the first and last reading environment and vocalization scale, reading speed, word recognition, and reading comprehension of more than one fluent reading methods and techniques (repetitive reading, mumble reading, rhyming reading, reading aloud, and expanding the vision spectrum) applied to the student with fluent reading problem Pre-test and post-test scores of the level are included.

\section{Pre-practice findings}

A text named "Excitement at Its Peak" was given to the student for pre-practice. The student could read 63 words in 3.5 minutes from the text, which is at the 4th-grade level and consists of 121 words. These data were analyzed according to the specified scales and rubrics, and the results are explained below.

Table 3. Environment and Vocalization Scale Scores for the First Measurement According to the Text "Excitement at Its Peak"

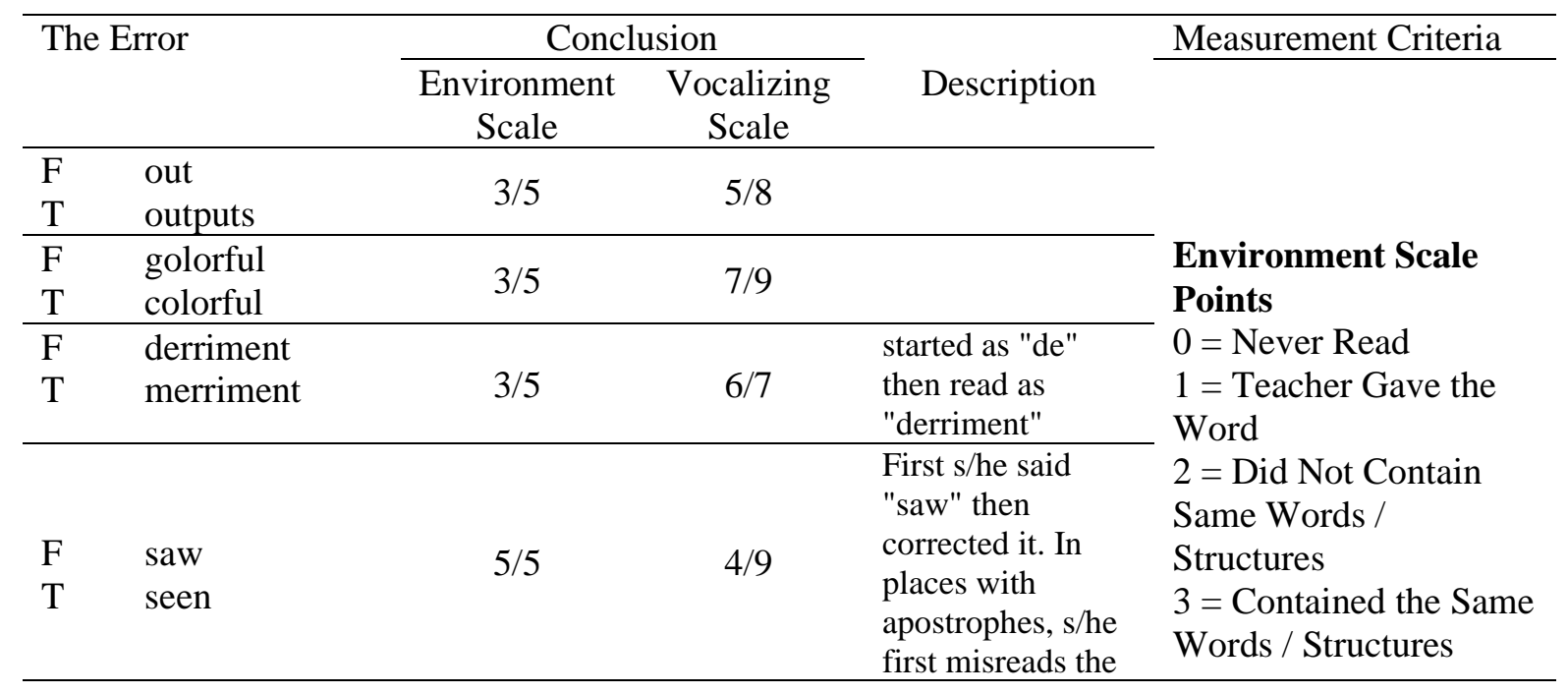




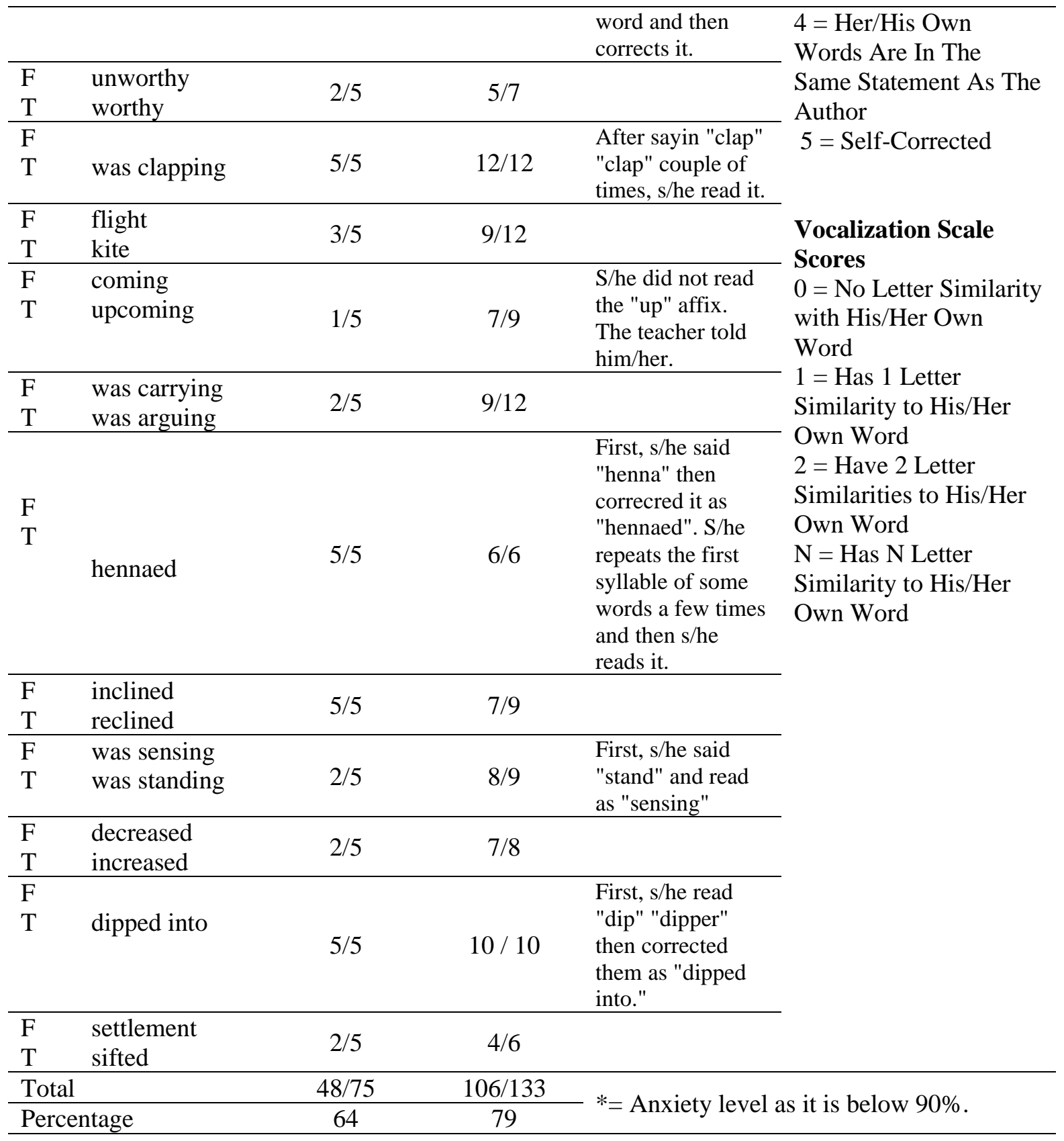

Table 4. Scores of the Comprehension Scale for the First Measurement According to the Text "Excitement at Its Peak"

\begin{tabular}{|c|c|c|c|c|}
\hline \multicolumn{2}{|r|}{ Questions and Answers } & Description & Score & \multirow{4}{*}{$\begin{array}{l}\text { Measurement Criteria } \\
\text { For Literal } \\
\text { Comprehension } \\
\text { Questions } \\
0=\text { Questions That } \\
\text { Never Answered } \\
1=\text { Semi-Answered } \\
\text { Questions } \\
2=\text { Fully Answered } \\
\text { Questions }\end{array}$} \\
\hline $\begin{array}{l}\text { Q } \\
\mathrm{A}\end{array}$ & $\begin{array}{l}\text { When did the children climb the hill? } \\
\text { While the whistle is blowing }\end{array}$ & $\begin{array}{l}\text { The question is } \\
\text { the literal } \\
\text { comprehension } \\
\text { question. }\end{array}$ & $2 / 2$ & \\
\hline $\begin{array}{l}\text { Q } \\
\mathrm{A}\end{array}$ & $\begin{array}{l}\text { How did the kites ascend to the sky? } \\
\text { By flying }\end{array}$ & $\begin{array}{l}\text { The question is } \\
\text { the literal } \\
\text { comprehension } \\
\text { question. }\end{array}$ & $1 / 2$ & \\
\hline $\begin{array}{l}\text { Q } \\
\mathrm{A}\end{array}$ & $\begin{array}{l}\text { Which kites were eliminated? } \\
\text { All of them }\end{array}$ & $\begin{array}{l}\text { The question is } \\
\text { the literal } \\
\text { comprehension } \\
\text { guestion }\end{array}$ & $0 / 2$ & \\
\hline
\end{tabular}

\section{For In-Depth}


Total

$3 / 6$

\section{Comprehension \\ Questions}

$0=$ Questions That

Never Answered

$1=$ Incomplete

Answered Questions

2 = Expected But

Incomplete Answers

$3=$ Complete and

Percentage

$*=$ Anxiety level as

$50 \%$

According to the measurement results, the range of 99+ (99-100) is free level, the range of 91-98 percent is the education level, and the range of 90-below is the level of anxiety in terms of word recognition level. In terms of comprehension level, 90+ (90-100) range is the free level, 75 percent (51-89) range is the free level, and 50- (50 and below) range is anxiety level (Ekwall and Shanker, 1988 as cited in Akyol, 2003). According to the findings in Table 3, the student got 64 points from the environment scale and 79 points from the vocalization scale. These results indicates that the student is at an anxiety level in terms of word recognition level according to the above data. According to the findings in Table 3, the student got 50 points from the comprehension scale. Again, when compared with the above data, it is detected that the student is at an anxiety level in terms of his/her level of understanding.

While the student is reading, s/he leans away from the paper and sometimes follows with his/her finger. The student can voice the words. However, the student makes the following mistakes while reading; reading the word not as it is spelled but as a different word in the same root ( in the text, s/he read the wordkite as flight), reading the word, s/he cannot read as another word similar in shape to it (in the text, s/he read the wordarguingas carrying), In places with apostrophes, reading the word incorrectly at first and then correcting it, repeating the first syllable of long words a few times, and then reading it (in the text, s/he read the word clappingafter saying "clap" "clap" couple of times), not reading suffixes at the end of some words (in the text, s/he read the wordupcoming as coming). In the rest of the text, 3 questions at the literal comprehension level were asked. The reason for asking few questions at the literal comprehension level is that there is also a problem in the student's reading comprehension skills based on the fluent reading problems. The student answered one of these questions correctly, gave an answer that could mean the same as the correct answer to one, and gave an incorrect answer to another question. The student made 15 mistakes in 63 words that s/he read in 3.5 minutes. According to the analysis results made according to the scales above, the student is a reader at an aniety level.

The percentage of word recognition, reading speed, reading prosody, and reading comprehension in the text s/he read were examined to evaluate the student's reading fluency. For this, reading percentage and speed calculations were made, evaluations were made according to the reading prosody and reading comprehension rubric, and the results are explained in Table 5. 
Table 5. Reading Fluency Pre-Practice Scores

\begin{tabular}{lcc}
\hline Word Recognition & \multicolumn{1}{c}{ Number of Correctly Read Words } & $79 \%$ \\
\cline { 2 - 3 } & \multicolumn{2}{c}{ Total Number of Words Read } \\
\hline Reading Speed & Correct Number of Words Read Per Minute & 19 \\
\hline \multirow{4}{*}{ Prosody } & $>$ Expression and Sound Level: & 2 \\
\cline { 2 - 3 } & $>$ Meaning Units and Intonation: & 1 \\
\cline { 2 - 3 } & $>$ Smoothness: & 2 \\
\cline { 2 - 3 } & $>$ Speed: & 7 \\
\cline { 2 - 3 } & $>$ Total Score: & 3 \\
\hline Reading Comprehension & & \\
\hline
\end{tabular}

Akyol, Rasinski et al. (2014), word recognition percentage is in the range of 92-98 percent at the instructional reading level, and the independent reading level accuracy rate points to the range of 99-100 percent. Some criteria related to reading speed have been enhanced by Güneş (2013) based on many practices. According to these criteria, it is expected for the 1st-grade students to read 60 words per minute, for 2nd-grade students to 80 words per minute, for 3rd-grade students to 100 words per minute, for 4th-grade students to 120 words per minute, and 5th-grade students to read 140 words per minute. It is not a cause for concern if the student scores eight or less from the sum of the prosody rubric's sub-dimensions at the beginning of the academic year or during the preimplementation of a study. However, if the student scored eight or below at the end of the academic year or the final stage of a study, this situation is problematic. It indicates that the student needs additional practices or instruction to develop the reading prosody (Akyol, Rasinski, et al., 2014). According to evaluating reading comprehension through a reading comprehension rubric, a student who scores three or fewer in the rubric infers that $\mathrm{s} / \mathrm{he}$ does not understand the text and does not remember the text's information. At the end of the academic year or the practice, the student is expected to score between 4-6 (Akyol, Rasinski, et al., 2014).

According to the reading fluency, pre-practice scores indicated in Table 5, the student's word recognition percentage was found to be 79 . This percentage indicates that the student is below the instructional reading level. The number of words the student read in a minute was found to be 19. This number is well below these criteria when compared with the criteria for reading according to grade level. Because, according to these criteria, a 5th-grade student should read an average of 80-140 words in 1 minute. The student got a total of 7 points according to the sub-dimensions of the reading prosody rubric. Since this stage is a pre-practice, this total score is not worrisome in terms of reading prosody. The student got 3 points according to the reading comprehension rubric. Since this stage is a pre-practice, the student's score in reading comprehension is considered normal.

\section{Findings related to the final practice}

After the fluent reading studies, two different texts were read to determine how much the student's fluent reading level made inroads into. The first of these texts is the "Excitement at Its Peak" text consisting of 121 words at the 4th-grade level, which was taught in the pre-practice phase. The second is the 5th-grade text titled "Marbling Art," consisting of 165 words. The student could read the text titled "Excitement at Its Peak" 
consisting of 121 words in 4.28 minutes, and the text called "Marbling Art," consisting of 165 words in 5.53 minutes. These data were analyzed according to the specified scales and rubrics, and the results are explained below.

Table 6. Environment and Vocalization Scale Scores for the First Measurement According to the Text "Excitement at Its Peak"

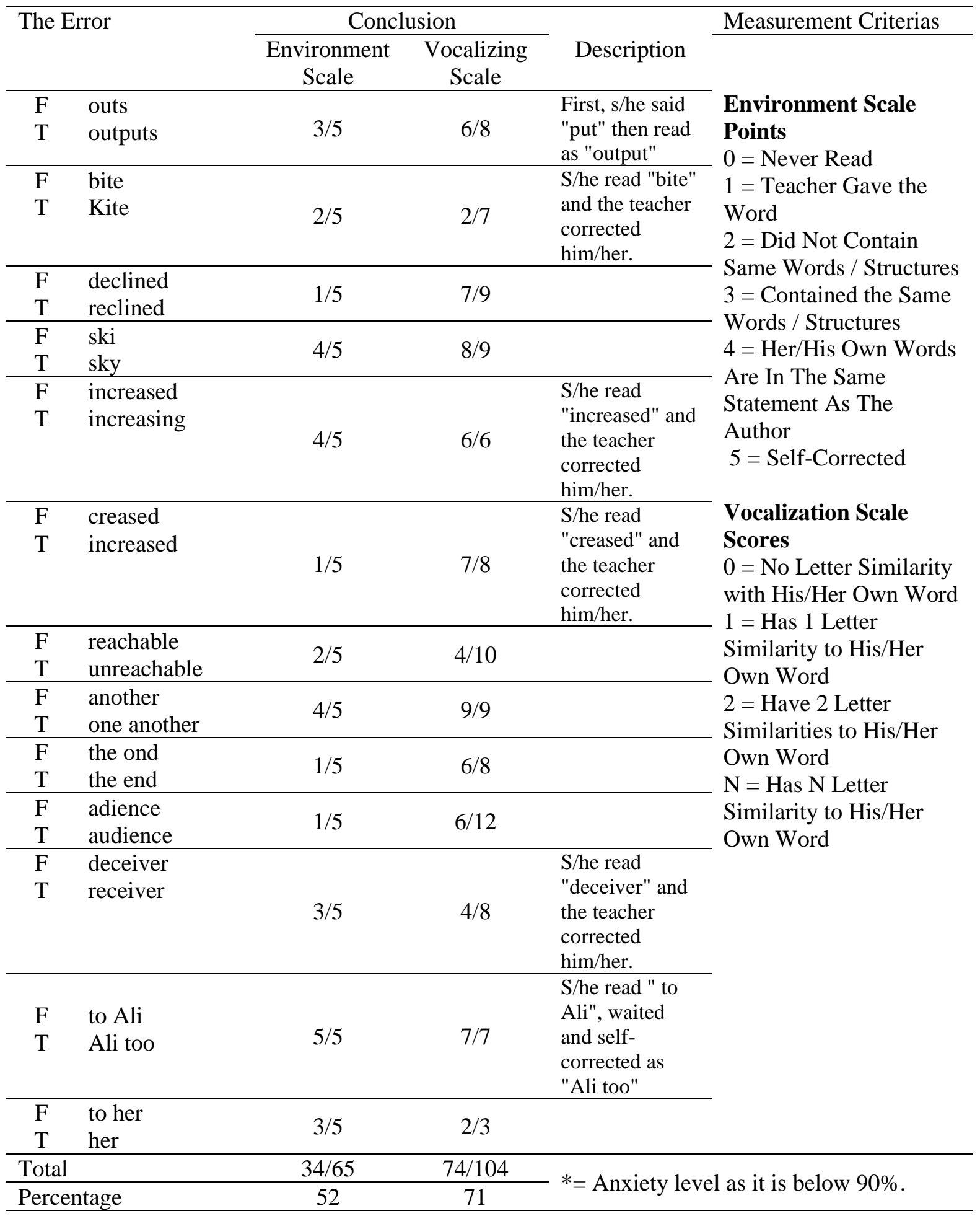


Table 7. Scores of the Comprehension Scale for the First Measurement According to the Text "Excitement at Its Peak"

\begin{tabular}{|c|c|c|c|}
\hline Questions and Answers & Description & Score & Measurement Criterias \\
\hline $\begin{array}{l}\text { Q How did the kites ascend to the sky? } \\
\text { A They ascended swiftly }\end{array}$ & $\begin{array}{l}\text { The question is } \\
\text { the literal } \\
\text { comprehension } \\
\text { question. }\end{array}$ & $2 / 2$ & $\begin{array}{l}\text { For Literal } \\
\text { Comprehension } \\
\text { Questions } \\
0=\text { Questions That Never }\end{array}$ \\
\hline $\begin{array}{l}\text { Q What were people discussing? } \\
\text { A The kite }\end{array}$ & $\begin{array}{l}\text { The question is } \\
\text { the literal } \\
\text { comprehension } \\
\text { question. }\end{array}$ & $1 / 2$ & $\begin{array}{l}\text { Answered } \\
1=\text { Semi-Answered } \\
\text { Questions } \\
2=\text { Fully Answered }\end{array}$ \\
\hline $\begin{array}{l}\text { Q Which kites were eliminated? } \\
\text { A } \quad \text { Beyoğlu's, Recep's, Ali's }\end{array}$ & $\begin{array}{l}\text { The question is } \\
\text { the literal } \\
\text { comprehension } \\
\text { question. }\end{array}$ & $0 / 2$ & $\begin{array}{l}\text { Questions } \\
\text { For In-Depth } \\
\text { Comprehension }\end{array}$ \\
\hline $\begin{array}{l}\text { Q Whose kites were left in the sky? } \\
\text { A Beyoğlu's and Ali's }\end{array}$ & $\begin{array}{l}\text { The question is } \\
\text { the literal } \\
\text { comprehension } \\
\text { question. }\end{array}$ & $1 / 2$ & $\begin{array}{l}\text { Questions } \\
0=\text { Questions That Never } \\
\text { Answered } \\
1=\text { Incomplete Answered }\end{array}$ \\
\hline $\begin{array}{l}\text { Q Why did the majority of the audience } \\
\text { drown in sadness? } \\
\text { A Their kites fell down }\end{array}$ & $\begin{array}{l}\text { The question is } \\
\text { the literal } \\
\text { comprehension } \\
\text { question. }\end{array}$ & $0 / 2$ & $\begin{array}{l}\text { Questions } \\
2=\text { Expected But } \\
\text { Incomplete Answers } \\
3=\text { Complete and }\end{array}$ \\
\hline $\begin{array}{l}\text { Q What was given to the winner? } \\
\text { A A bicycle }\end{array}$ & $\begin{array}{l}\text { The question is } \\
\text { the literal } \\
\text { comprehension } \\
\text { question. }\end{array}$ & $2 / 2$ & $*=$ Anxiety level as it is \\
\hline
\end{tabular}

Total

$6 / 12$

Percentage

According to the measurement results, the range of 99+ (99-100) is free level, the range of 91-98 percent is the education level, and the range of 90-below is the level of anxiety in terms of word recognition level. In terms of comprehension level, 90+ (90-100) range is the free level, 75 percent (51-89) range is the free level, and 50- (50 and below) range is anxiety level (Ekwall and Shanker, 1988 as cited in Akyol, 2003). The student read the entire text of 121 words in 4.28 minutes. S/he made 13 mistakes while reading. Following the text, six questions about the text were addressed to the student. More questions were asked to the student in the final practice than the pre-practice because of determining the development of the student's reading comprehension skill after the practice. The student gave full answers to 2 of these questions, semi-answers to 2, and incorrect answers to 2 of these questions. According to Table 6, the student got 52 points from the environment scale and 71 points from the vocalization scale. According to the data above, these results indicate that the student is at an anxiety level in terms of word recognition level. According to the findings in Table 6, the student got 50 points from the comprehension scale. Again, when compared with the above data, it is detected that the student is at an anxiety level in terms of his/her level of understanding. 
To evaluate the student's reading fluency after the last practice, the percentage of word recognition, reading speed, reading prosody, and reading comprehension status was examined in the text s/he read. For this, reading percentage and speed calculations and evaluations were made according to the reading prosody and reading comprehension rubric, and the results are explained in Table 8.

Table 8. Reading Fluency Final Practice Scores

\begin{tabular}{|c|c|c|}
\hline \multirow[t]{2}{*}{ Word Recognition } & Number of Correctly Read Words & \multirow[t]{2}{*}{$88 \%$} \\
\hline & Total Number of Words Read & \\
\hline Reading Speed & Correct Number of Words Read Per Minute & 40 \\
\hline \multirow{5}{*}{ Prosody } & $>$ Expression and Sound Level: & 3 \\
\hline & $>$ Meaning Units and Intonation: & 2 \\
\hline & $>$ Smoothness: & 2 \\
\hline & $>$ Speed: & 3 \\
\hline & Total Score: & 10 \\
\hline \multicolumn{2}{|c|}{ Reading Comprehension } & 4 \\
\hline
\end{tabular}

Akyol, Rasinski et al. (2014), word recognition percentage is in the range of 92-98 percent at the instructional reading level, and the independent reading level accuracy rate points to the range of 99-100 percent. Some criteria related to reading speed have been enhanced by Güneş (2013) based on many practices. According to these criteria, it is expected for the 1st-grade students to read 60 words per minute, for 2nd-grade students to 80 words per minute, for 3rd-grade students to 100 words per minute, for 4th-grade students to 120 words per minute, and 5th-grade students to read 140 words per minute. It is not a cause for concern if the student scores eight or less from the sum of the prosody rubric's sub-dimensions at the beginning of the academic year or during the preimplementation of a study. However, if the student scored eight or below at the end of the academic year or the final stage of a study, this situation is problematic. It indicates that the student needs additional practices or instruction to develop the reading prosody (Akyol, Rasinski, et al., 2014). According to evaluating reading comprehension through a reading comprehension rubric, a student who scores three or fewer in the rubric infers that $s /$ he does not understand the text and does not remember the text's information. At the end of the academic year or the practice, the student is expected to score between 4-6 (Akyol, Rasinski, et al., 2014).

According to the reading fluency final practice scores indicated in Table 8, the student's word recognition percentage was 88 . This percentage indicates that the student is below the instructional reading level. The number of words the student read in a minute was found to be 40 . This number is well below these criteria when compared with the criteria for reading according to grade level. Because, according to these criteria, a 5thgrade student should read an average of 80-140 words in 1 minute. The student got a total of 10 points according to the sub-dimensions of the reading prosody rubric. This total score received by the student is appropriate in terms of reading prosody. The student got 4 points according to the reading comprehension rubric. The score the student got for reading comprehension is appropriate according to the determined criteria. 
Another text taught in the last practice stage is the text called "Marbling Art" at the 5th-grade level. This text consists of 165 words. The student read this text in 5.53 minutes. These data were analyzed according to the specified scales and rubrics, and the results are explained below.

Table 9. Environment and Vocalization Scale Scores for the First Measurement According to the Text "Marbling Art"

\begin{tabular}{|c|c|c|c|c|c|}
\hline \multirow{2}{*}{\multicolumn{2}{|c|}{ The Error }} & \multirow{2}{*}{\multicolumn{2}{|c|}{ Conclusion }} & \multirow{2}{*}{ Description } & \multirow[t]{3}{*}{ Measurement Criterias } \\
\hline & & & & & \\
\hline $\begin{array}{l}\mathrm{F} \\
\mathrm{T}\end{array}$ & $\begin{array}{l}\text { ranch } \\
\text { branch }\end{array}$ & $4 / 5$ & $6 / 7$ & & \\
\hline $\begin{array}{l}\mathrm{F} \\
\mathrm{T}\end{array}$ & $\begin{array}{l}\text { patter } \\
\text { patterns }\end{array}$ & $1 / 5$ & $3 / 8$ & $\begin{array}{l}\text { S/he read } \\
\text { "patter" and the } \\
\text { teacher } \\
\text { corrected } \\
\text { him } / \text { her. }\end{array}$ & $\begin{array}{l}\text { Points } \\
0=\text { Never Read } \\
1=\text { Teacher Gave the } \\
\text { Word } \\
2=\text { Did Not Contain }\end{array}$ \\
\hline $\begin{array}{l}\mathrm{F} \\
\mathrm{T}\end{array}$ & $\begin{array}{l}\text { cloudy } \\
\text { cloudlike }\end{array}$ & $3 / 5$ & $5 / 9$ & & Same Words / Structures \\
\hline $\begin{array}{l}\mathrm{F} \\
\mathrm{T}\end{array}$ & $\begin{array}{l}\text { make } \\
\text { make-up }\end{array}$ & $2 / 5$ & $6 / 8$ & $\begin{array}{l}\text { S/he read } \\
\text { "make" and the } \\
\text { teacher } \\
\text { corrected } \\
\text { him/her as } \\
\text { "make-up" }\end{array}$ & $\begin{array}{l}\text { Words / Structures } \\
4=\text { Her/His Own Words } \\
\text { Are In The Same } \\
\text { Statement As The } \\
\text { Author }\end{array}$ \\
\hline $\begin{array}{l}\mathrm{F} \\
\mathrm{T}\end{array}$ & $\begin{array}{l}\text { patient } \\
\text { patience }\end{array}$ & $1 / 5$ & $2 / 5$ & $\begin{array}{l}\text { S/he read } \\
\text { "patient" and } \\
\text { the teacher } \\
\text { corrected } \\
\text { him/her. }\end{array}$ & $\begin{array}{l}5=\text { Self-Corrected } \\
\text { Vocalization Scale } \\
\text { Scores } \\
0=\text { No Letter Similarity }\end{array}$ \\
\hline $\begin{array}{l}\mathrm{F} \\
\mathrm{T}\end{array}$ & $\begin{array}{l}\text { a wide } \\
\text { wide and }\end{array}$ & $2 / 5$ & $5 / 7$ & $\begin{array}{l}\text { Teacher } \\
\text { corrected }\end{array}$ & $\begin{array}{l}\text { with His/Her Own Word } \\
1=\text { Has } 1 \text { Letter }\end{array}$ \\
\hline $\begin{array}{l}\mathrm{F} \\
\mathrm{T}\end{array}$ & $\begin{array}{l}\text { sought } \\
\text { ought }\end{array}$ & $4 / 5$ & $5 / 7$ & & $\begin{array}{l}\text { Similarity to His/Her } \\
\text { Own Word }\end{array}$ \\
\hline $\begin{array}{l}\mathrm{F} \\
\mathrm{T}\end{array}$ & $\begin{array}{l}\text { with } \\
\text { within }\end{array}$ & $4 / 5$ & $5 / 5$ & . & $\begin{array}{l}2=\text { Have } 2 \text { Letter } \\
\text { Similarities to His/Her }\end{array}$ \\
\hline $\begin{array}{l}\mathrm{F} \\
\mathrm{T}\end{array}$ & $\begin{array}{l}\text { pat } \\
\text { put }\end{array}$ & $2 / 5$ & $3 / 5$ & $\begin{array}{l}\text { S/he read "pat" } \\
\text { and the teacher } \\
\text { corrected } \\
\text { him/her as } \\
\text { "put" }\end{array}$ & $\begin{array}{l}\text { Own Word } \\
\mathrm{N}=\text { Has N Letter } \\
\text { Similarity to His/Her } \\
\text { Own Word }\end{array}$ \\
\hline $\begin{array}{l}\mathrm{F} \\
\mathrm{T}\end{array}$ & $\begin{array}{l}\text { in caps } \\
\text { in cups }\end{array}$ & $1 / 5$ & $7 / 11$ & $\begin{array}{l}\text { S/he read "in } \\
\text { caps" and the } \\
\text { teacher } \\
\text { corrected } \\
\text { him/her. }\end{array}$ & \\
\hline $\begin{array}{l}\mathrm{F} \\
\mathrm{T}\end{array}$ & $\begin{array}{l}\text {-on } \\
\text { upon }\end{array}$ & $4 / 5$ & $8 / 8$ & & \\
\hline $\begin{array}{l}\mathrm{F} \\
\mathrm{T}\end{array}$ & $\begin{array}{l}\text { drippings } \\
\text { droppings }\end{array}$ & $1 / 5$ & $5 / 12$ & $\begin{array}{l}\text { S/he read } \\
\text { "drippings" and } \\
\text { the teacher } \\
\text { corrected } \\
\text { him/her. }\end{array}$ & \\
\hline $\begin{array}{l}\mathrm{F} \\
\mathrm{T}\end{array}$ & $\begin{array}{l}\text { surprise } \\
\text { surprising }\end{array}$ & $3 / 5$ & $8 / 9$ & & \\
\hline $\mathrm{F}$ & patten & $1 / 5$ & $6 / 8$ & S/he read & \\
\hline
\end{tabular}




\begin{tabular}{cccl}
\hline T patterns & & $\begin{array}{l}\text { "paten" and the } \\
\text { teacher } \\
\text { corrected } \\
\text { him/her. }\end{array}$ \\
\hline $\mathrm{F} \quad \begin{array}{l}\text { pater } \\
\mathrm{T} \quad \text { patterns }\end{array}$ & $1 / 5$ & $6 / 8 \quad \begin{array}{l}\text { S/he read } \\
\text { "paten" and the } \\
\text { teacher } \\
\text { corrected } \\
\text { him/her. }\end{array}$ \\
\hline Total & $34 / 75$ & $80 / 117$ & $*$ Anxiety level as it is below $90 \%$. \\
\hline Percentage & 45 & 68 & $*=$ An \\
\hline
\end{tabular}

Table 10. Scores of the Comprehension Scale for the First Measurement According to the Text "Marbling Art"

\begin{tabular}{|c|c|c|c|}
\hline \multicolumn{2}{|r|}{ Questions and Answers } & Description & Score \\
\hline $\begin{array}{l}\text { Q } \\
A\end{array}$ & $\begin{array}{l}\text { Where can you find marbling? } \\
\text { In art }\end{array}$ & $\begin{array}{l}\text { The question is } \\
\text { the literal } \\
\text { comprehension } \\
\text { question. }\end{array}$ & $0 / 2$ \\
\hline A & $\begin{array}{l}\text { How do colors and patterns create } \\
\text { an image in marbling art? } \\
\text { Rectangular }\end{array}$ & $\begin{array}{l}\text { The question is } \\
\text { the literal } \\
\text { comprehension } \\
\text { question. }\end{array}$ & $0 / 2$ \\
\hline $\begin{array}{l}\text { Q } \\
A\end{array}$ & $\begin{array}{l}\text { What does the preparation of } \\
\text { marbling require? } \\
\text { It requires clothes and decorations }\end{array}$ & $\begin{array}{l}\text { The question is } \\
\text { the literal } \\
\text { comprehension } \\
\text { question. }\end{array}$ & $0 / 2$ \\
\hline $\begin{array}{l}\text { Q } \\
\text { A }\end{array}$ & $\begin{array}{l}\text { How is the art of marbling done? } \\
\text { Please explain. } \\
\text { Tables, tablecloths and curtains }\end{array}$ & $\begin{array}{l}\text { The question is } \\
\text { the literal } \\
\text { comprehension } \\
\text { question. }\end{array}$ & $0 / 2$ \\
\hline Q & $\begin{array}{l}\text { Where can we see marbling } \\
\text { patterns? } \\
\text { Everywhere }\end{array}$ & $\begin{array}{l}\text { The question is } \\
\text { the literal } \\
\text { comprehension } \\
\text { question. }\end{array}$ & $1 / 2$ \\
\hline
\end{tabular}

Total

Measurement Criterias

For Literal

Comprehension

Questions

$0=$ Questions That Never

Answered

$1=$ Semi-Answered

Questions

2 = Fully Answered

Questions

For In-Depth

Comprehension

Questions

$0=$ Questions That Never

Answered

1 = Incomplete Answered

Questions

2 = Expected But

Incomplete Answers

$3=$ Complete and

Effective Answers

$*=$ Anxiety level as it is $50 \%$

Percentage

10

According to the measurement results, the range of 99+ (99-100) is free level, the range of 91-98 percent is the education level, and the range of 90-below is the level of anxiety in terms of word recognition level. In terms of comprehension level, 90+ (90-100) range is the free level, 75 percent (51-89) range is the free level, and 50- (50 and below) range is anxiety level (Ekwall and Shanker, 1988 as cited in Akyol, 2003). The student read the entire text of 165 words in 5.53 minutes. S/he made 15 mistakes while reading. Following the text, five questions about the text were addressed to the student. The student answered 4 of these questions incorrectly and gave semi-answers to 2 of them. According 
to the findings in Table 9, the student got 45 points from the environment scale and 68 points from the vocalization scale. These results indicates that the student is at an aniety level in terms of word recognition level according to the above data. According to the findings in Table 10, the student got 10 points from the comprehension scale. Again, when compared with the above data, it is detected that the student is at an anxiety level in terms of his/her level of understanding.

After the last practice, the percentage of word recognition, reading speed, reading prosody, and reading comprehension in the text s/he read (Marbling Art text) were examined to evaluate the student's reading fluency. For this, reading percentage and speed calculations and evaluations were made according to the reading prosody and reading comprehension rubric, and the results are explained in Table 11.

Table 11. Reading Fluency Post-Practice Scores (Marbling Art Text)

\begin{tabular}{|c|c|c|}
\hline \multirow[t]{2}{*}{ Word Recognition } & Number of Correctly Read Words & \multirow[t]{2}{*}{$93 \%$} \\
\hline & Total Number of Words Read & \\
\hline Reading Speed & Correct Number of Words Read Per Minute & 40 \\
\hline \multirow{5}{*}{ Prosody } & $>$ Expression and Sound Level: & 3 \\
\hline & $>$ Meaning Units and Intonation: & 2 \\
\hline & $>$ Smoothness: & 2 \\
\hline & Speed: & 3 \\
\hline & Total Score: & 10 \\
\hline \multicolumn{2}{|c|}{ Reading Comprehension } & 4 \\
\hline
\end{tabular}

Akyol, Rasinski et al. (2014), word recognition percentage is in the range of 92-98 percent at the instructional reading level, and the independent reading level accuracy rate points to the range of 99-100 percent. Some criteria related to reading speed have been enhanced by Güneş (2013) based on many practices. According to these criteria, it is expected for the 1st-grade students to read 60 words per minute, for 2nd-grade students to 80 words per minute, for 3rd-grade students to 100 words per minute, for 4th-grade students to 120 words per minute, and 5 th-grade students to read 140 words per minute. It is not a cause for concern if the student scores eight or less from the sum of the prosody rubric's sub-dimensions at the beginning of the academic year or during the preimplementation of a study. However, if the student scored eight or below at the end of the academic year or the final stage of a study, this situation is problematic. It indicates that the student needs additional practices or instruction to develop the reading prosody (Akyol, Rasinski, et al., 2014). According to evaluating reading comprehension through a reading comprehension rubric, a student who scores three or fewer in the rubric infers that $\mathrm{s} / \mathrm{he}$ does not understand the text and does not remember the text's information. At the end of the academic year or the practice, the student is expected to score between 4-6 (Akyol, Rasinski, et al., 2014).

According to the reading fluency (Marbling Art Text) scores indicated in Table 11, the student's word recognition percentage was 93. This percentage indicates that the student is at the instructional reading level. The number of words the student read in a minute was found to be 40 . This number is well below these criteria when compared with the criteria for reading according to grade level. Because, according to these criteria, a 5th- 
grade student should read an average of 80-140 words in 1 minute. The student got a total of 10 points according to the sub-dimensions of the reading prosody rubric. This total score received by the student is appropriate in terms of reading prosody. The student got 4 points according to the reading comprehension rubric. The score the student got for reading comprehension is appropriate according to the determined criteria.

\section{Discussion}

In reading studies based on more than one fluent reading method and technique, it is detected that there is a mathematical increase in the development of the student's reading skills even if the student remains at the level of anxiety. When similar studies (Akyol and Sever, 2019; Çayır and Balc1, 2017) which conducted to overcome fluent reading problems in our country are examined, it is observed that their results do not provide an improvement in the reading level of the student, as in the results of this study, but provide a mathematical increase in reading skills. In the the studies that Sağlam, Baş and Akyol (2020); Erbasan and Sağlam (2020); Kuruoğlu and Şen (2019); Kanık Uysal and Akyol (2019); Karasakaloğlu and Saraçlı Çelik (2018); Akyol and Ketenoğlu Kayabaşı (2018); Sözen and Akyol (2018); Akyol and Kodan (2016); Kardaş İşler and Şahin (2016); Çeliktürk Sezgin and Akyol (2015); Yamaç (2014); Duran and Sezgin (2012), conducted, it was observed that students with fluent reading problems both improved their reading levels and their reading skills increased in a mathematical sense. The results of this research and similar research in the literature reveals that when one-to-one reading studies are done with students with fluent reading problems, reading problems decrease, and reading skills improve. These results display the effectiveness of reading programs prepared for students with fluent reading problems.

\section{Suggestions for practice}

This study was conducted for fifteen lesson hours based on the determined reading methods and techniques. Based on the research results, it is suggested that the practices to be done to solve fluent reading problems should be done for a longer period. Besides, it is recommended to experiment with different reading methods, techniques, and strategies, diversify the reading materials to be used, and practice the student's problem by recognizing the student to be applied well.

\section{Conclusion}

More than one fluent reading method and technique (repetitive reading, mumble reading, rhyming reading, reading aloud, and expanding the vision spectrum) was performed along with 15 lesson hour practice to overcome the student's fluent reading problem in this study's scope. Then, the results obtained within the scope of this study, in which the student's reading speed, word recognition level, and reading comprehension skills were measured, are as follows: The student remained at the level of concern in terms of word recognition and comprehension level in the post-practice as was in the prepractice. However, there was a mathematical increase in the development of reading skills. In the pre-practice, the student's word recognition percentage was 79, the number of words read per minute was 19 , her/his prosody score was 7 , and her/his reading comprehension 
score was 3 in the text taught at the 4th-grade level. In the final practice, the student's word recognition rate increased to 88 , the number of correct words read per minute to 40 , his prosody score to 10 , and his reading comprehension score to 4 in the 4th-grade level text taught in the pre-practice. In the final practice, the student's percentage of word recognition increased to 93 , the number of correct words read per minute to 40 , her/his prosody score to 10 , and her/his reading comprehension score to 4 in her/his grade level (5th grade) text.

In addition to the development of the reading skills described above, it was observed that there was a decrease in some reading errors in the student. While the student was reading, her/his behavior of leaning away from the paper decreased, and s/he stopped finger tracking completely. The ability to read the first syllable of long syllable words a few times and then read it is no longer available. S/he can read long syllable words in one snap. Despite these improvements, some reading errors persist. These are; reading the word not as it is written but as a different word in the same root, reading the word that cannot be read as another word similar to it in shape, and not reading the suffixes at the end of some words.

\section{References}

Akyol, H. (2011). Turkish first reading and writing teaching (10th edition). Pegem Akademi Publishing.

Akyol, H., Rasinski, T. V., Yıldırım, K., Ateş, S. \& Çetinkaya, Ç. (2014). Evaluating reading. Pegem Akademi Publishing.

Akyol, H. \& Sever, E. (2019). Literacy difficulty and action research: a second-grade example. Hacettepe University Journal of Faculty of Education, 34(3), 685-707.

Akyol, H. \& Ketenoğlu Kayabaşı, Z. E. (2018). Improving the reading skills of a student with reading disabilities: an activity research. Education and Science, 43(193), 143-158.

Akyol, H. \& Kodan, H. (2016). Practice intended to overcome reading disabilities: the use of fluent reading strategies. Ondokuz Mayls University Journal of Faculty of Education, 35(2), 7-21.

Büyüköztürk, Ş., Kılıç Çakmak, E., Akgün, Ö. E., Karadeniz, Ş. \& Demirel, F. (2018). Scientific research methods. Pegem Akademi Publishing

Çayır, A. \& Balcı, E. (2017). The effect of an individualized reading program on the reading skills of an elementary school student at risk of dyslexia. International Journal of Turkish Literature Culture Education, 6(1), 455-470.

Coşkun, C. \& Çeçen, M. (2012). Fast and comprehendingly reading technique. BS Publication Printing Distribution

Çeliktürk Sezgin, Z. \& Akyol, H. (2015). Improving the reading skills of fourth-grade students with reading disabilities. Turkish Journal of Education, 4(2).

Duran, E. \& Bitir, T. (2020). Reading education (2nd edition). Vizetek Publishing.

Duran, E. \& Sezgin, B. (2012). The effect of the guided reading method on fluent reading. Journal of Gazi Educational Faculty, 32(3), 633-655.

Ekwall, E. E. \& Shanker, J. L. (1988). Diagnosis and Remedation of the Disabled Reader. (Third Edition). Allyn and Bacon Inc. (p.403-415).

Erbasan, Ö. \& Sağlam, A. (2020). Improving reading skills of homeschooling students with reading disabilities. Journal of Basic Education, 2(1), 14-25. 
Güneş, F. (2017). Turkish teaching approaches and models (5th edition). Pegem Akademi Publishing.

Gürkaner, M. \& Güven, S. (2020). Examination of graduate theses on reading fluently performed at primary school level in Turkey. Nevşehir Hacı Bektaş Veli Universirty Journal of SBE, 10(1), 347-363.

Karasakaloğlu, N. \& Saraçlı Çelik, S. (2018). The contribution of the guided reading method to primary school students' listening comprehension levels and their fluent reading skills. Turkish Studies, 13 (19), 1083-1100.

Kanık Uysal, P. \& Akyol, H. (2019). Reading disabilities and overcoming it: activity research. Education and Science, 44(198), 17-35.

Kardaş İşler, N. \& Şahin, A. E. (2016) Reading disorder and comprehension difficulty of a primary school 4th-grade student: a case study. Journal of Mother Tongue Education, 4(2), 174186.

Kuruoğlu, G. \& Şen, N. (2019). The effect of accelerated reading education for secondary school students with reading disabilities. Journal of Buca Educational Faculty, 47, 36-45.

Özbay, M. (2007). Turkish special teaching methods II. Öncü Kitap

Rasinski, T. V. \& Padak, N. (2005). 3-minute reading assessment (Grade 1-4): Word recognation, fluency comprehension. Scholastic Inc.

Sağlam, A., Baş, Ö. \& Akyol, H. (2020). The effect of word repetition technique on the fluent reading levels of third-grade gifted students. Journal of History School, 46, 1605-1629.

Samuels, S. Jay. (1997). The method of repeated readins. The Reading Teacher, 50, 376-381.

Sidekli, S. \& Yangın, S. (2005). A practice aimed at improving the reading skills of students with reading disabilities. Atatürk University Journal of Kazım Karabekir Educational Faculty, (41), 82-100.

Sözen, N. \& Akyol, H. (2018). Guided reading method: activity research. Turkish Studies, 13(19), 1633-1658.

Ünalan, Ş. (2006). Turkish Education. Nobel Publishing.

Yamaç, A. (2014). A practice aimed at increasing the reading fluency of a primary school fourthgrade student. K.U. Kastamonu Education Journal, 23 (2),631-644.

Zutell, J. \& Rasinski, T. V. (1991). Training teachers to attend to their students oral reading fluency. Theory into Practice, 30, 211-217. 


\title{
Dil Eğitimi ve Araştırmaları Dergisi
}

\author{
Araştırma Makalesi
}

\section{Akıcı Okuma Sorunu Olan Bir Öğrenci Üzerine Okumayı Geliştirici Çalışmalar Yapma ve Değerlendirme}

\author{
Cengiz Kesik $^{*} \quad$ Meliha Efe Kesik $^{* *}$
}

\section{MAKALE BÍLGISİ}

Alınma 17.03.2021

Revize edilmiş form 02.04 .2021

Kabul edilme 20.04.2021

Doi:10.31464/jlere.898499

Anahtar Kelimeler:

Akıcl okuma

Kelime tanıma

Okuma hızı

Okuduğunu anlama

Prozodi

\begin{abstract}
ÖZET
$\mathrm{Bu}$ araştırmada akıcı okuma probleminin giderilmesinde kullanılan birden fazla akıcı okuma yöntem ve tekniğinin (tekrarlı okuma, mırıltılı okuma, kafiyeli okuma, sesli okuma ve görme yelpazesini genişletme) etkisini belirlemek amaçlanmıştır. Amaçlı örnekleme yöntemlerinden ölçüt örnekleme yönteminin kullanıldığı araştırmada, akıcı okuma sorunu olduğu tespit edilen beşinci sınıf öğrencisi ile çalışma yapılmıştır. Araştırma okul kütüphanesinde belirlenen saatlerde birer gün arayla toplam onbeş ders saati olarak belirlenen yöntem ve tekniklerle akıcı okuma çalışmaları yapmak biçiminde düzenlenmiştir. Araştırmanın verileri betimsel istatistiklerle analiz edilmiştir. Araştırmada çalışma yapılan öğrencinin kelime tanıma düzeyi ve okuduğunu anlama düzeyinde matematiksel olarak bir ilerleme olsa da öğrenci serbest düzeye geçemeyip endişe düzeyinde kalmıştır. Araştırmada akıcı okuma sorununun giderilmesinde kullanılan birden fazla akıcı okuma yöntem ve tekniğinin öğrencinin okuma hızı, kelime tanıma yüzdesi ve prozodisinde matematiksel olarak ilerleme sağlamada ve öğrencide görülen bazı okuma hatalarını azaltmada etkili olduğu sonucuna ulaşılmıştır.
\end{abstract}

\footnotetext{
* Araştırma Görevlisi, ORCID ID: https://orcid.org/0000-0001-9777-0076, Harran Üniversitesi, Temel Eğitim Bölümü, cengiz_kesik@hotmail.com

** Sınıf Öğretmeni, ORCID ID: https://orcid.org/0000-0002-5882-2475, Milli Eğitim Bakanlığı, melihaaa_93@live.de
} 


\section{Giriș}

Geçmişten günümüze kadar okuma ile ilgili çeşitli tanım ve açıklamalar yapılmıştır. Eskiden "okuma" denilince yazıların şifresini çözme olarak anlaşılıyor ve yüksek sesle okumaya ağırlık veriliyordu. Daha sonraları kelimeleri bütün olarak görme ve zihne yerleştirme şeklinde açıklanan okuma, günümüzde dil ve zihin becerilerini geliştirme olarak ele alınmaktadır. Okuma, ön bilgilerle metindeki bilgilerin bütünleştirildiği ve yeniden anlamlandırıldığı bir süreçtir. Bu süreç görme, seslendirme, anlama, zihinde yapılandırma gibi göz, ses ve beynimizin çeşitli işlemlerinden oluşmaktadır. Önce çizgi, harf veya sembollerin algılanmasıyla başlamakta, ardından dikkat yoğunlaştırılarak kelime ve cümlelerin anlamı bulunmaktadır (Güneş, 2017). Ancak bazı öğrenciler bu becerileri tam olarak yerine getirememekte ve dolasıyla akıcı bir şekilde okuyamamaktadır. Bu öğrencilerin yavaş okuma nedenleri şu şekilde sıralanabilir (Akyol, 2011): hece hece okuma, yavaş kelime tanıma, kelime kelime okuma, fısıldayarak okuma, dudak hareketleri yapma, sessiz (iç) konuşma, parmakla takip, kafa hareketleri, okuma sırasında geri dönmeler ve satırdan satıra geçiş.

Belirtilen yavaş okuma nedenlerinin önüne geçip çocukta akıcı okuma becerilerini geliştirmek için belli aşama, yöntem ve tekniklere göre çalışmalar yapılmaktadır. Bu yöntem ve teknikler, sesli okuma, sessiz okuma, hızlı okuma, rehberli okuma, tam okuma, metinler arası okuma, tartışarak okuma, göz atarak okuma, not alarak okuma, altını çizerek okuma, seçmeli okuma, okuma tiyatrosu, söz korosu, soru sorarak okuma, tahmin ederek okuma, özetleyerek okuma, ezber yaparak okuma, eleştirel okuma, şiir okuma, görsel okuma, atlayarak okuma, ekran okuma, dönüşümlü okuma, tekrarlı okuma, eşleşmeli okuma, koro okuma, mırıltılı okuma, arkadaşlı okuma, işbirlikli tekrarlı okuma, radyo okuma, yankılayıcı okuma, simetrik harflerle ritimli okuma, kafiyeli okuma, görme yelpazesini genişletme, performans okuma ve kaydederek okuma olarak sıralanmaktadır (Duran ve Bitir, 2020; Güneş, 2017). Sıralanan okuma yöntem ve teknikleri belli aşamalara göre uygulanmaktadır. Bu aşamalar okumaya hazırlık ve okuma planlama çalışmalarının yapıldığı okuma öncesi aşama; kelimeleri doğru telaffuz edip, cümle, paragraf ve metni anlama, bilgiyi zihinde yapılandırma ve uygulama çalışmalarının yapıldığı okuma aşaması; metinde aktarılan bilgileri değerlendirme, sorgulama, eleştirme ve yorumlama çalışmalarının yapıldığı okuma sonrası aşamadır (Güneş, 2017).

\section{Literatür incelemesi}

Okuma eğitimi ile ilgili literatür incelendiğinde farklı okuma aşamaları, yöntem ve tekniklerine göre farklı sınıf düzeylerindeki çocuklarla çalışmalar yapıldığı görülmektedir. Sağlam, Baş ve Akyol (2020), üçüncü sınıf özel yetenekli çocuklarla yaptıkları çalışmada kelime tekrar tekniğinin üçüncü sınıf özel yetenekli çocukların sesli okuma hatalarını giderdiği, akıcı okuma ve okuduğunu anlama becerilerini geliştirmede faydalı olduğu, çocukların okuma yaparken vurgu ve tonlamaya dikkat etme ile duraksama oranlarında artış olduğunu belirtmektedir. Erbasan ve Sağlam (2020), okuma güçlüğü olan evde eğitim ögrencisinin akıcı okuma ve okuduğunu anlama becerilerinin geliştirilmesinde rehberli okuma tekniğinin olumlu etkilerinin olduğunu açıklamaktadır. Akyol ve Sever (2019), okuma yazma güçlüğü çeken ilkokul ikinci sınıf öğrencisi için Fernald yöntemi, yankılı ve 
tekrarlı okuma stratejileri ile yaptıkları uygulamada öğrencinin uygulama öncesi okuyamadığı metnin 30 kelimesini okuyabildiği, okuma esnasında 8 okuma hatası yaptığı, okuma istediğinin arttığı, sesli okumaya başladığı, okuduklarını fark ettiğini ve yazısının okunaklılık düzeyinin orta düzeyi yükseldiğini belirtmektedir. Kuruoğlu ve Şen (2019), okuma güçlüğü yaşayan ortaokul öğrencilerine uygulanan hızlandırılmış okuma eğitiminin öğrencilerin okuma hızı ve sesli okuma düzeylerini istatistiksel olarak anlamlı düzeyde yükselttiğini vurgulamaktadır. Kanık Uysal ve Akyol (2019), okuma güçlüğü yaşayan bir yedinci sınıf öğrencisinin okuma ve anlama problemlerinin giderilmesine yönelik tekrarlı, model, yardımlı, yankılı ve koro okuma modellerini kapsayan bir eylem planı hazırlamışlar ve uygulamalar sonrası öğrencinin okuma düzeyinin endişe düzeyinden öğretimsel düzeye ulaştığını belirtmektedirler. Karasakaloğlu ve Saraçlı Çelik (2018), rehberli okuma yönteminin okuma güçlüğü yaşayan ilkokul üçüncü sınıf öğrencilerinin okuma, okuduğunu ve dinlediğini anlama becerilerinin gelişimine katkı sağladığı ayrıca çocuklarla birebir çalışma ve yönlendirmenin çocukların yazılarının düzelmesi, soruya göre cevap yazma becerisinin gelişmesi ve noktalama işaretlerini doğru kullanma konusunda fark edilir bir iyileşme sağladığını belirtmektedir. Akyol ve Ketenoğlu Kayabaşı (2018), okuma güçlüğü yaşayan bir öğrenci için hazırladıkları okuma güçlüğü programda 15 saat ses, hece ve kelime üzerinde durduklarını, 15 saat ise eşli okuma ve tekrarlı okuma yöntemi ile okuma akıcılığı üzerinde durduklarını belirtip bu program sayesinde öğrencinin okuma ve anlama düzeyinin endişe düzeyinden öğretim düzeyine yükseldiğini belirtmektedir. Sözen ve Akyol (2018) da rehberli okuma yöntemiyle yaptıkları çalışmada rehberli okuma yöntemin okuma güçlügü olan ilkokul üçüncü sınıf öğrencilerinin okuma güçlüklerinin giderilmesinde ve anlama becerilerinin geliştirilmesine katkı sağladığını belirtmektedir. Çayır ve Balcı (2017), okuma yetersizliği olan bir ilkokul üçüncü sınıf öğrencisi için eko okuma, tekrarlı okuma ve birtakım okuma stratejilerinden oluşan bir okuma programı hazırlayıp uygulama yapmışlar ve uygulama sonunda öğrencinin yaşadığı okuma güçlüklerinin önemli ölçüde azaldığını ancak okuma akıcılığında istenilen düzeye ulaşılmadığını belirtmektedirler. Akyol ve Kodan (2016), okuma güçlüğü yaşayan bir ilkokul dördüncü sınıf öğrencisi için tekrarlayıcı, eşli, yankılayıcı ve bağımsız okuma stratejilerinin uygulandığı 45 saatlik okuma programı hazırlamışlar, uygulama sonrası öğrencinin okuma ve anlama düzeyinde gelişme olduğu gözlemlenmiştir. Kardaş İşler ve Şahin (2016), okuma güçlüğü çeken bir ilkokul dördüncü sınıf öğrencisiyle paragrafın önceden dinlenilmesi stratejisi ve eşli okuma stratejisine dayalı uygulamalar yapmışlar ve uygulama sonunda öğrencinin okuma ve okuduğunu anlama sorunlarında azalma olduğu gözlemlemişlerdir. Çeliktürk Sezgin ve Akyol (2015), okuma güçlüğü olan dördüncü sınıf öğrencisinin okuma becerilerinin geliştirilmesi amacıyla tekrarlı okuma, eşli okuma ve okuyucu tiyatroları teknikleriyle yaptıkları uygulamada öğrencinin kelime tanıma ve anlama düzeyinin endişe düzeyinden öğretim düzeyine çıktığını açıklamaktadırlar. Yamaç (2014), okuma güçlüğü çeken bir dördüncü sınıf öğrencisinin okuma akıcıllı̆ını geliştirmek amacıyla tekrarlı okuma, eşli okuma ve kelime inşası tekniğiyle uygulamalar yapmış ve uygulama sonunda öğrencinin kelime tanıma becerisinin endişe düzeyinden serbest düzeye, okuma hızının dakikada 20.8'den 34.2'ye ve prozodi puanının ise \%15'den $\% 66$ 'ya yükseldiğini belirtmektedir. Duran ve Sezgin (2012) rehberli okuma yönteminin ilkokul öğrencilerinin (1-4. sınıf) akıcı okumalarına etkisine bakıldığı çalışmada rehberli 
okuma yönteminin ilkokul öğrencilerinin sesli okuma hatalarını azalttığı, kelime tanıma yüzdesi ve anlama düzeylerini arttırdı̆̆ 1 , sesli okuma becerilerini ise endişe düzeyinden öğretim düzeyine çıktığını belirtmektedirler. Sidekli ve Yangın (2005), okuma güçlüğü yaşayan beşinci öğrencilerine çoklu duyusal yaklaşımlarla uygulamalar yapmışlar ve uygulamalar sonunda öğrencinin okuma düzeyinin endişe düzeyinden öğretimsel düzeye doğru geliştiğini belirtmektedirler. Gürkaner ve Güven (2020) ise 2012-2018 y1lları arasında Türkiye'de ilkokul düzeyinde akıcı okuma üzerine yapılmış lisansüstü tezleri inceledikleri çalışmada bu yıllar arasında yapılmış lisansüstü tezlerde akıcı okuma strateji, yöntem ve tekniklerinden eşli okuma, koro okuma, yapılandırılmış okuma, tekrarlı okuma, SQ3R, altı dakika yöntemi, yankılayıcı okuma, okuma tiyatroları ve paylaşarak okumanın kullandığı görülmüştür. Bu strateji, yöntem ve tekniklere dayalı olarak yapılan lisansüstü tezlerin sonuçlarında çocukların okuma hızları, doğru okuma becerileri, prozodik okuma becerileri, okuduğunu anlama, akademik başarı ve okuma motivasyonlarında olumlu yönde gelişmeler olmuştur. Bu bulgular farklı amaç ve yöntemlerle akıcı okuma üzerine çalışmaların yapıldı̆̆ını göstermektedir.

Akıcı okuma becerilerinin geliştirilmesinde uygulanan strateji, yöntem ve teknik ne olursa olsun bu konuda önemli olan sınıf öğretmeninin ilgisi ve akıcı okuma problemi olan öğrencilerine zaman ayırmasıdır. Akıcı okuma ile ilgili literatür incelendiğinde akıcı okuma probleminin giderilmesinde farklı okuma yöntem, teknik ve stratejilerine dayalı olarak programlar hazırlandığı ve uygulamalar yapıldığı görülmektedir (Sağlam, Baş ve Akyol, 2020; Erbasan ve Sağlam, 2020; Akyol ve Sever, 2019; Kuruoğlu ve Şen, 2019; Kanık Uysal ve Akyol, 2019; Karasakaloğlu ve Saraçlı Çelik, 2018; Akyol ve Ketenoğlu Kayabaş1, 2018; Sözen ve Akyol, 2018; Çayır ve Balc1, 2017; Akyol ve Kodan, 2016; Kardaş İşler ve Şahin, 2016; Çeliktürk Sezgin ve Akyol, 2015; Yamaç, 2014; Duran ve Sezgin, 2012; Sidekli ve Yangın, 2005). Bu çalışmada ise ilgili literatürde uygulanan okuma yöntem, teknik ve stratejilerinden farklı olarak tekrarlı okuma, mırıltılı okuma, kafiyeli okuma, sesli okuma ve görme yelpazesini genişletme yöntem ve tekniklerinin kullanılmış olması nedeniyle bu yöntem ve tekniklere dayalı uygulamaların akıcı okuma çalışmalarına örnek teşkil etmesi açısından önemli olduğu düşünülmektedir. Sesli okuma, bireyin gördüğü ve zihninde kavradığı kelime ve kelime gruplarını konuşma organıyla seslendirmesidir (Ünalan, 2006; Duran ve Bitir,2020). Sesli okumadaki temel amaç bireyin okuduğu metindeki kelimeleri doğru telaffuz edip, bu sözcüklerin taşıdığı anlamı dikkate alarak okumalarını sağlamaktır (Özbay, 2007). Tekrarlı okuma, kısa bir metnin okuma güçlüğü çeken bireye akıcı okumaya ulaşıncaya kadar tekrar tekrar okutulmasıdır (Samules, 1997). Bu tekrarlar bir yetişkin rehberliğinde yapılır. Metinler kolaydan zora doğru okutulur. $\mathrm{Bu}$ yöntemdeki amaç bireylerin sözcük tanıma hızlarını arttırmak ve anlamaya daha fazla vakit ayırmalarını sağlamaktır. Kafiyeli okuma; yapı bakımından kafiye mısra sonlarındaki seslerin benzeşmesidir. Kafiyeli okuma ise kafiyeli mısraların oluşturduğu şiirleri okumadır. Kafiyeli okuma bireylerin eğlenerek okumalarını, ses farkındalıklarının gelişimini ve akıcı okuma becerilerini geliştirebilir. Görme yelpazesini genişletme, okuma güçlüğü çeken bireylere hızla okumanın öğretilmesi amacıyla farklı geometrik şekillerden oluşan metinlerin okutulmasına dayalı etkinliklerin uygulandığ çalışmalardır (Güneş, 2015). Mırıltılı okuma ise kısık ve alçak bir sesle belli dudak 
hareketlerine dayalı olarak yapılan okumadır. Tekrarlı okuma, mırıltılı okuma, kafiyeli okuma, sesli okuma ve görme yelpazesini genişletme yöntem ve teknikleri ile öğrencideki okuma hızı, kelime tanıma düzeyi ve okuduğunu anlama test edilmek istenmiştir. Bundan hareketle bir öğrencinin akıcı okuma probleminin giderilmesinde belirtilen birden fazla akıcı okuma yöntem ve tekniğinin kullanılması amaçlanmıştır. $\mathrm{Bu}$ amaç doğrultusunda aşağıdaki problem ve alt problemlere cevap aranmıştır.

\section{Araştırmanın problem cümlesi}

Akıcı okuma probleminin giderilmesinde birden fazla akıcı okuma yöntem ve tekniğinin (tekrarlı okuma, mırıltılı okuma, kafiyeli okuma, sesli okuma ve görme yelpazesini genişletme) kullanılmasının bir etkisi var mıdır?

\section{Alt problemler}

Akıcı okuma problemin giderilmesinde birden fazla akıcı okuma yöntem ve tekniğinin kullanılmasının;

a. Okuma hızı, kelime tanıma yüzdesi ve prozodisine etkisi var mıdır?

b. Kelime tanıma düzeyine etkisi var mıdır?

c. Okuduğunu anlama düzeyine etkisi var mıdır?

\section{Yöntem}

\section{Araştırma tasarımı ve yayın etiği}

Araştırmanın amacı doğrultusunda araştırmada nicel araştırma yöntemlerinden tek denekli araştırma yöntemi kullanılmıştır. Bazı özel durumlarda deneysel çalışmaların yapılacağı evrendeki birey sayısı az olabilir. Örneğin özel eğitim gerektiren bireylerle yürütülecek bir çalışmalarda yapılacak olan deney tek bir bireye ve bu bireye özgü olarak geliştirilebilir (Büyüköztürk, Kılıç Çakmak, Akgün, Karadeniz ve Demirel, 2018, s.18). Bu kapsamda araştırma akıcı okuma problemi olan bir öğrenci ile yürütülmüştür. Bu makalede araştırma ve yayın etiğine bağlı kalınmıştır.

\section{Bağlam}

Bu çalışma 2018-2019 eğitim öğretim yılında bir ortaokulda gerçekleştirilmiştir.

\section{Çalışma grubu}

Araştırmanın çalışma grubunda yer alan öğrencinin belirlenmesinde amaçlı örnekleme yöntemlerinden ölçüt örnekleme kullanılmıştır. Ölçüt örnekleme, bir araştırmadaki gözlem birimlerinin belli niteliklere sahip kişiler, olaylar, nesneler veya durumlardan oluşmasıdır (Büyüköztürk vd., 2018: 91). Çalışma grubunda yer alan öğrenci 2018-2019 eğitim-öğretim yılında Millî Eğitim Bakanlığına Bağlı bir resmi ortaokulda, beşinci sınıfta öğrenim gören akıcı okuma problemi olan, okuma konusunda arkadaşlarına ve sınıf seviyesine göre geride olan bir öğrencidir. Öğrenciyle ilgili bazı demografik bilgiler Tablo 1'de açıklanmıştır. 
Tablo 1. Çalışmaya Katılan Öğrencinin Demografik Bilgileri

\begin{tabular}{ll}
\hline Cinsiyet & Erkek \\
Sinıf seviyesi & 5 \\
Baba eğitim durumu & İlkokul \\
Baba mesleği & Çalışmıyor \\
Anne eğitim durumu & İlkokul \\
Anne mesleği & Ev hanımı \\
Kardeş sayısı & 3 \\
Sosyoekonomik durumu & Düşük
\end{tabular}

Tablo 1'de görüldüğü gibi çalışmaya katılan öğrenci 5.sınıf düzeyindedir. Öğrencinin belirlenme sürecinde dersine giren öğretmenleriyle görüşülmüş, öğrencinin ders içi performansı, akademik başarısı ve genel durumuyla ilgili bilgiler alınmıştır. Bu öğrenci, herhangi bir öğrenme güçlüğü bulunmayan sadece akıcı okuma sorunu olan bir öğrencidir. Öğrenci sosyoekonomik düzeyi düşük bir aileden gelmekte, babası çalışmamakta annesi ise ev hanımıdır. Ailenin üçüncü çocuğudur. Öğrencinin sürekli bir hastalığı ve kullandığı herhangi bir ilaç yoktur. Öğrencinin 4 yıllık ilkokul öğrenimi sürecinde 3 farklı sınıf öğretmeni dersine girmiştir. Yani her yıl farklı bir sınıf öğretmeni dersine girmiştir.

\section{Veri toplama araçları}

\section{Yanlış analiz envanteri}

$\mathrm{Bu}$ envanter, Ekwall ve Shanker (1988) tarafından geliştirilmiş ve Akyol (2003) tarafından uyarlanmıştır. Ortam ve seslendirme ölçeği (sesli okuma sırasında yapılan hatalarla kelime ve ses bilgisini, sessiz olarak metin okunduktan sonra da sorulan sorularla anlama becerisini ve düzeyini belirleme), kelime tanıma yüzdesi (Öğrencinin 60 saniyelik sesli okuma sırasında doğru olarak okuduğu kelimelerin yüzdesi hesaplanarak belirlenir. $\mathrm{Bu}$ yüzde, doğru okunan kelimelerin sayısının, toplam okunan kelimelerin sayısına bölünmesi ile belirlenir.) ve okuma hızından (Öğrencinin 60 saniyelik okuma süresinde doğru olarak okuduğu kelime sayısıdır.) oluşmaktadır.

\section{Okuma prozodisi rubriğgi}

Zutell ve Rasinski (1991) tarafından geliştirilmiş ve Yıldırım, Yıldız ve Ateş (2009) tarafından Türkçeye uyarlanmıştır. İfade ve ses düzeyi, anlam üniteleri ve tonlama, pürüzsüzlük ve hız olmak üzere 4 boyuttan oluşur. Yapılan okuma uygulamaları sonucu öğrencinin bu rubrikten en az 8 ve üstü puan alması gerekmektedir. 8'in altında puan alan öğrencinin ek uygulamalara ihtiyacı vardır.

\section{Okuduğunu anlatmayla okuduğunu anlamayı değerlendirme rubriği}

Rasinski ve Padak (2005) tarafından geliştirilmiş, Akyol, Rasinski, Yıldırım, Ateş ve Çetinkaya (2014) tarafından Türkçeye uyarlanmıştır. Yapılan okuma uygulamaları sonucu öğrencinin bu rubrikten 4-6 puan aralığında puan alması gerekmektedir. Öğrencinin aldığı puan 3 veya 3 'ün altındaysa öğrencinin ek uygulamalara ihtiyacı vardır. 


\section{Prosedür}

\section{Ön uygulama aşaması}

$\mathrm{Bu}$ aşamada öğrenciye 4.sınıf düzeyinde, 121 kelimeden oluşan "Heyecan Doruklarda" adlı metin verilmiştir. Bu metin MEB ilkokul 4.sınıf Türkçe ders kitabından alınmıştır. Öğrenci metni okurken ses kaydı alınmıştır. Bu ses kaydı aşağıdaki veri toplama araçlarına göre analiz edilerek, öğrencinin mevcut okuma düzeyi belirlenmiştir. $\mathrm{Bu}$ veri toplama araçları: Ortam ve Seslendirme Ölçeği, Kelime Tanıma Yüzdesi, Okuma Hızı, Okuma Prozodisi Rubriği ve Okuduğunu Anlatmayla Okuduğunu Anlamayı Değerlendirme Rubriği'dir.

\section{Akıcı okuma çalışmaları}

Öğrencinin mevcut okuma düzeyi belirlendikten sonra araştırmacılar tarafından öğrenciye uygulanmak üzere bir okuma programı hazırlanmıştır. Bu okuma programı literatürdeki farklı akıcı okuma yöntem ve teknikleri dikkate alınarak seçilmiştir. Bu akıcı okuma yöntem ve teknikleri; tekrarlı okuma, mirıltılı okuma, kafiyeli okuma, sesli okuma ve görme yelpazesini genişletmedir [GYP]. Hazırlanan okuma programı araştırmacılardan biri tarafından okul kütüphanesinde belirlenen saatlerde 15 ders saati uygulanmıştır. Her bir ders saati 40 dakika sürmüştür. Okuma programı kapsamında okutulan metinler Coşkun ve Çeçen'in (2012) Hızlı ve Anlayarak Okuma Tekniği kitabından alınmıştır. Okuma programının hangi saatinde hangi metnin okutulduğu, hangi okuma yöntem ve tekniğinin uygulandığg Tablo 2'de açıklanmıştır.

Tablo 2. Akııı Okuma Çalışmaları

\begin{tabular}{cll}
\hline Uygulama Saati & Okutulan Metin & Okuma Yöntem ve Tekniği \\
\hline 16. Saat & Kedi & Kafiyeli, Sesli ve Tekrarlı Okuma \\
\hline 17. Saat & Enginar & Sesli ve Tekrarlı Okuma \\
\hline 18. Saat & Sonbahar Geldi & Sesli ve Tekrarlı Okuma \\
\hline 19. Saat & Nasreddin Hoca & Kafiyeli, Sesli ve Tekrarlı Okuma \\
\hline 20. Saat & Öğretmenim & Kafiyeli, Sesli ve Tekrarlı Okuma \\
\hline 21. Saat & Zeki Koş & GYP, Sesli ve Tekrarlı Okuma \\
\hline 22. Saat & Engin Uyan & GYP, Sesli ve Tekrarlı Okuma \\
\hline 23. Saat & Karınca ile Güvercin & GYP, Sesli ve Tekrarlı Okuma \\
\hline 24. Saat & Anne Kalbi & GYP, Sesli ve Tekrarlı Okuma \\
\hline 25. Saat & Son Pişmanlık & GYP, Sesli ve Tekrarlı Okuma \\
\hline 26. Saat & Atatürk’ün Bir Saati Vardı & Kafiyeli, Sesli ve Tekrarlı Okuma \\
\hline 27. Saat & Dövüşçü Aslan ile Yaban Domuzu & Mrrıltıl1, Sesli ve Tekrarlı Okuma \\
\hline 28. Saat & Salyangoz ile Evi & Mrrıltılı, Sesli ve Tekrarlı Okuma \\
\hline 29. Saat & Aman Allahım Plana Bak & Mırıltıl1, Sesli ve Tekrarlı Okuma \\
\hline 30. Saat & İyiliğe Karşı Kötülük & Mrrıltılı, Sesli ve Tekrarlı Okuma \\
\hline & &
\end{tabular}

\section{Son uygulama aşaması}

Akıcı okuma çalışmaları bittikten sonra öğrencinin ne duruma geldiğini belirlemek amacıyla öğrenciye "Heyecan Doruklarda" metni tekrar okutulmuş ve bunun ardından ise kendi sınıf düzeyinde, 165 kelimeden oluşan "Ebru Sanatı" adlı metin de okutulmuştur. "Ebru Sanatı" adlı metin Akyol, Yıldırım, Ateş, Çetinkaya ve Rasinski'nin (2014) Okumayı Değerlendirme adlı kitabından alınmıştır. Öğrenciye son uygulamada iki farklı 
metin okutulmasının sebebi ön uygulamada okutulan kendi sınıf düzeyinin altındaki (4.sınıf) metinde ne düzeye geldiğini ve kendi sınıf düzeyindeki (5.sınıf) metinde ise hangi düzeye geldiğini görmedir. Öğrencinin kendi sınıf düzeyine göre akıcı okuma problemi olduğundan ön uygulama sadece 4. sınıf düzeyinde tek bir metin okutulmuştur. Öğrenci metinleri okurken ses kaydı alınmıştır. Bu ses kaydı aşağıdaki veri toplama araçlarına göre analiz edilerek, öğrencinin nerden nereye geldiği belirlenmiştir. Bu veri toplama araçları: Ortam ve Seslendirme Ölçeği (Ekwall ve Shanker), Kelime Tanıma Yüzdesi, Okuma Hızı, Okuma Prozodisi Rubriği ve Okuduğunu Anlatmayla Okuduğunu Anlamayı Değerlendirme Rubriğidir.

\section{Bulgular}

$\mathrm{Bu}$ bölümde, akıcı okuma problemi olan öğrenciye uygulanan birden fazla akıcı okuma yöntem ve tekniğinin (tekrarlı okuma, mırıltılı okuma, kafiyeli okuma, sesli okuma ve görme yelpazesini genişletme) ilk ve son okuma ortam ve seslendirme ölçeği, okuma hızı, kelime tanıma ve okuduğunu anlama düzeyi ön test ve son test puanlarına ilişkin bulgulara yer verilmiştir.

\section{Ön uygulamaya ilişkin bulgular}

Ön uygulama yapmak için öğrenciye "Heyecan Doruklarda" adlı metin verilmiştir. 4.sınıf düzeyinde olan ve 121 kelimeden oluşan bu metni, öğrenci 3.5 dakikada 63 kelimesini okuyabilmiştir. Bu veriler belirlenen ölçek ve rubriklere göre analiz edilmiş ve sonuçları aşağıda açıklamıştır.

Tablo 3. "Heyecan Doruklarda" Metnine Göre İlk Ölçüm İçin Ortam ve Seslendirme Ölçeği Puanlar1

\begin{tabular}{|c|c|c|c|c|c|}
\hline \multicolumn{2}{|c|}{ Yapılan Hata } & \multicolumn{2}{|c|}{ Sonuç } & \multirow[b]{2}{*}{ Açıklama } & \multirow[t]{3}{*}{ Ölçüm Kriterleri } \\
\hline & & $\begin{array}{l}\text { Ortam } \\
\text { Ölçeği }\end{array}$ & $\begin{array}{l}\text { Seslendirme } \\
\text { Ölçeği }\end{array}$ & & \\
\hline $\begin{array}{l}Y \\
D\end{array}$ & $\begin{array}{l}\text { çıkar } \\
\text { cıktılar }\end{array}$ & $3 / 5$ & $5 / 8$ & & \\
\hline $\begin{array}{l}\text { Y } \\
D\end{array}$ & $\begin{array}{l}\text { negarenk } \\
\text { rengarenk }\end{array}$ & $3 / 5$ & $7 / 9$ & & \multirow{5}{*}{$\begin{array}{l}\text { Ortam Ölçeği } \\
\text { Puanları } \\
0=\text { Hiç Okumadı } \\
1=\text { Kelimeyi Öğretmen } \\
\text { Verdi } \\
2=\text { Aynı } \\
\text { Kelimeleri/Yapıları } \\
\text { İçermedi } \\
3=\text { Aynı } \\
\text { Kelimeleri/Yapıları } \\
\text { İçerdi } \\
4=\text { Kendi Koyduğu } \\
\text { Kelimeler Yazarla Aynı } \\
\text { İfadede } \\
5=\text { Kendini Düzeltti }\end{array}$} \\
\hline $\begin{array}{l}\text { Y } \\
D\end{array}$ & $\begin{array}{l}\text { dümbüşü } \\
\text { cümbüşü }\end{array}$ & $3 / 5$ & $6 / 7$ & $\begin{array}{l}\text { “dü” diye başladı } \\
\text { sonra "dümbüşü" } \\
\text { olarak okudu }\end{array}$ & \\
\hline $\begin{array}{l}\text { Y } \\
\text { D }\end{array}$ & $\begin{array}{l}\text { gördü } \\
\text { görülmeye }\end{array}$ & $5 / 5$ & $4 / 9$ & $\begin{array}{l}\text { Önce "gördü" dedi } \\
\text { sonra düzeltti. } \\
\text { Kesme işareti olan } \\
\text { yerlerde önce } \\
\text { kelimeyi yanlış } \\
\text { okuyor, sonra } \\
\text { düzeltiyor. }\end{array}$ & \\
\hline $\begin{array}{l}\text { Y } \\
D\end{array}$ & $\begin{array}{l}\text { değildir } \\
\text { değerdi }\end{array}$ & $2 / 5$ & $5 / 7$ & & \\
\hline $\begin{array}{l}\text { Y } \\
D\end{array}$ & alkışlıyordu & $5 / 5$ & $12 / 12$ & $\begin{array}{l}\text { Birkaç kez "al" } \\
\text { "al" dedikten sonra } \\
\text { okudu }\end{array}$ & \\
\hline $\begin{array}{l}\mathrm{Y} \\
\mathrm{D}\end{array}$ & $\begin{array}{l}\text { uçmasının } \\
\text { ucurtmasının }\end{array}$ & $3 / 5$ & $9 / 12$ & & Seslendirme Ölçeği \\
\hline $\mathrm{Y}$ & olacağ1 & $1 / 5$ & $7 / 9$ & "n1" ekini & Puanları \\
\hline
\end{tabular}




\begin{tabular}{|c|c|c|c|c|c|}
\hline $\mathrm{D}$ & olacağını & & & $\begin{array}{l}\text { okumadı.Öğretmen } \\
\text { söyledi }\end{array}$ & \multirow{8}{*}{$\begin{array}{l}0=\text { Kendi Koyduğu } \\
\text { Kelimeyle Harf } \\
\text { Benzerliği Yok } \\
1=\text { Kendi Koyduğu } \\
\text { Kelimeyle 1 Harf } \\
\text { Benzerliği Var } \\
2=\text { Kendi Koyduğu } \\
\text { Kelimeyle } 2 \text { Harf } \\
\text { Benzerliği Var } \\
\text { N =Kendi Koyduğu } \\
\text { Kelimeyle N Harf } \\
\text { Benzerliği Var }\end{array}$} \\
\hline $\begin{array}{l}\mathrm{Y} \\
\mathrm{D}\end{array}$ & $\begin{array}{l}\text { taşıyordu } \\
\text { tartışıyordu }\end{array}$ & $2 / 5$ & $9 / 12$ & & \\
\hline $\begin{array}{l}Y \\
D\end{array}$ & kınalı & $5 / 5$ & $6 / 6$ & \multirow[t]{2}{*}{$\begin{array}{l}\text { kın" deyip sonra } \\
\text { kınalı olarak } \\
\text { düzeltti. Bazı } \\
\text { kelimelerin ilk } \\
\text { hecesini birkaç kez } \\
\text { tekrarlayıp sonra } \\
\text { okuyor. }\end{array}$} & \\
\hline $\begin{array}{l}\mathrm{Y} \\
\mathrm{D}\end{array}$ & $\begin{array}{l}\text { yaslandı } \\
\text { yaslanmış }\end{array}$ & $5 / 5$ & $7 / 9$ & & \\
\hline $\begin{array}{l}\mathrm{Y} \\
\mathrm{D}\end{array}$ & $\begin{array}{l}\text { duyuyordu } \\
\text { duruyordu }\end{array}$ & $2 / 5$ & $8 / 9$ & $\begin{array}{l}\text { Önce "duru" dedi } \\
\text { devaminda } \\
\text { "duyuyordu" } \\
\text { olarak okudu }\end{array}$ & \\
\hline $\begin{array}{l}\mathrm{Y} \\
\mathrm{D}\end{array}$ & $\begin{array}{l}\text { atmıştı } \\
\text { artmıșt1 }\end{array}$ & $2 / 5$ & $7 / 8$ & & \\
\hline $\begin{array}{l}\mathrm{Y} \\
\mathrm{D}\end{array}$ & çakılanlar & $5 / 5$ & $10 / 10$ & $\begin{array}{l}\text { Önce "çak", “çakı" } \\
\text { olarak okuyup } \\
\text { devamında } \\
\text { çakılanlar olarak } \\
\text { düzeltti }\end{array}$ & \\
\hline $\begin{array}{l}\text { Y } \\
\mathrm{D}\end{array}$ & $\begin{array}{l}\text { evden } \\
\text { elendi }\end{array}$ & $2 / 5$ & $4 / 6$ & & \\
\hline \multicolumn{2}{|c|}{ Toplam } & $48 / 75$ & $106 / 133$ & \multirow{2}{*}{\multicolumn{2}{|c|}{$\begin{array}{l}*=\% 90 \text { 'ın altında olduğu için endişe } \\
\text { düzeyi. }\end{array}$}} \\
\hline & & 64 & 79 & & \\
\hline
\end{tabular}

Tablo 4. "Heyecan Doruklarda" Metnine Göre İlk Ölçüm İçin Anlama Ölçeği Puanları

\begin{tabular}{|c|c|c|c|c|}
\hline \multicolumn{2}{|r|}{ Sorular ve Cevapları } & Açıklama & Puan & \multirow{6}{*}{$\begin{array}{l}\text { Derinlemesine Anlama } \\
\text { Soruları İçin } \\
\text { 0= Hiç Cevap } \\
\text { Verilmeyen Sorular } \\
\text { 1 = Çok Eksik Cevap } \\
\text { Verilen Sorular } \\
2 \text { = Beklenene Yakın } \\
\text { Ancak Eksik Olan } \\
\text { Cevaplar } \\
\text { 3 = Tam ve Etkili } \\
\text { Cevaplar } \\
\text { * = \% } 50 \text { olduğu için } \\
\text { endişe düzeyi }\end{array}$} \\
\hline $\begin{array}{l}\mathrm{S} \\
\mathrm{C}\end{array}$ & $\begin{array}{l}\text { Çocuklar ne zaman tepeye çıktılar? } \\
\text { Düdük öterken }\end{array}$ & $\begin{array}{l}\text { Soru basit } \\
\text { anlama } \\
\text { sorusudur. }\end{array}$ & $2 / 2$ & \\
\hline $\begin{array}{l}\mathrm{S} \\
\mathrm{C}\end{array}$ & $\begin{array}{lll}\text { Uçurtmalar } & \text { gökyüzüne } & \text { nasıl } \\
\text { yükseldi? } & & \\
\text { Uçarak } & & \\
\end{array}$ & $\begin{array}{l}\text { Soru basit } \\
\text { anlama } \\
\text { sorusudur. }\end{array}$ & $1 / 2$ & \\
\hline & $\begin{array}{l}\text { Hangi uçurtmalar elendi? } \\
\text { Hepsi }\end{array}$ & $\begin{array}{l}\text { Soru basit } \\
\text { anlama } \\
\text { sorusudur. }\end{array}$ & $0 / 2$ & \\
\hline \multicolumn{2}{|c|}{ Toplam } & & $3 / 6$ & \\
\hline \multicolumn{2}{|c|}{ Yüzde } & & $0.50^{*}$ & \\
\hline
\end{tabular}


Ölçüm sonuçlarına göre kelime tanıma düzeyi açısından 99+(99-100) aralığ1 serbest düzey, yüzde 91-98 aralığı öğretim düzeyi ve yüzde 90-altı aralığı ise endişe düzeyidir. Anlama düzeyi açısından ise 90+(90-100) aralığı serbest düzey, yüzde 75(5189) aralığı serbest düzey ve yüzde 50-(50 ve altı) aralığ1 endişe düzeyidir (Ekwall ve Shanker, 1988'den Aktaran Akyol, 2003). Tablo 3'teki bulgulara göre öğrenci ortam ölçeğinden 64 ve seslendirme ölçeğinden 79 puan almıştır. Bu sonuçlar yukarıdaki verileri göre öğrencinin kelime tanıma düzeyi açısından endişe düzeyinde olduğunu göstermektedir. Tablo 3'teki bulgulara göre ise öğrenci anlama ölçeğinden 50 puan almıştır. Yine yukarıdaki verilerle karşılaştırıldığında öğrencinin anlama düzeyi açısından da endişe düzeyinde olduğu görülmektedir.

Öğrenci okuma yaparken, kâğıda eğilip uzaklaşmakta ve ara ara parmağıyla takip etmektedir. Öğrenci kelimeleri seslendirebilmektedir. Ancak okurken şu hataları yapmaktadır; kelimeyi yazıldığı gibi değil de aynı kökte farlı bir kelime olarak okuma (metinde $\boldsymbol{u c ̧ u r t m a s ı n ı n ~ k e l i m e s i n i ~ u c ̧ m a s ı n ı n ~ o l a r a k ~ o k u d u ) , ~ o k u y a m a d ı g ̆ ı ~ k e l i m e y i ~ s ̧ e k l e n ~}$ ona benzer olan başka bir kelime olarak okuma (metinde tartışıyordu kelimesini taşıyordu olarak okudu), kesme işareti olan yerlerde kelimeyi ilk başta yanlış okuyup sonra düzeltme, uzun kelimelerin ilk hecesini birkaç kez tekrar edip sonra okuma (metinde alkışlıyordu kelimesini “al” “al” deyip sonra okudu), bazı kelimelerin sonundaki ekleri okumama (metinde olacă̆ını kelimesini olacă̆ı olarak okudu). Metnin devamında basit anlama düzeyinde 3 tane soru yöneltilmiştir. Basit anlama düzeyinde ve az sayıda soru sorulmasının sebebi öğrencinin akıcı okuma problemine dayalı olarak okuduğunu anlama becerisinde de problem olduğundan dolayıdır. Ö̆ğrenci, bu sorulardan birini doğru cevaplamıştır, birine doğru cevapla aynı anlama gelebilecek bir cevap vermiştir, diğer bir soruya ise yanlış cevap vermiştir. Öğrenci 3.5 dakikada okuduğu 63 kelimede 15 hata yapmıştır. Yukarıdaki ölçeklere göre yapılan analiz sonuçlarına göre öğrenci endişe düzeyinde bir okuyucudur.

Öğrencinin okuma akıcılığını değerlendirmek için okuduğu metinde kelime tanıma yüzdesine, okuma hızına, okuma prozodisine ve okuduğunu anlama durumuna bakılmıştır. Bunun için okuma yüzdesi ve hızı hesaplamaları yapılmış, okuma prozodisi ve okuduğunu anlama rubriğine göre değerlendirmeler yapılıp, sonuçları Tablo 5 'te açıklanmıştır.

Tablo 5. Okuma Akıcılığı Ön Uygulama Puanları

\begin{tabular}{lll}
\hline Kelime Tanıma & \multicolumn{1}{c}{ Doğru Okunan Kelime Sayısı } & $\% 79$ \\
\cline { 2 - 3 } & Okunan Toplam Kelime Sayısı & \\
\hline Okuma Hızı & Dakikada Okunan Doğru Kelime Sayısı & 19 \\
\hline \multirow{3}{*}{ Prozodi } & $>$ İfade ve Ses Düzeyi: & 2 \\
\cline { 2 - 3 } & $>$ Anlam Üniteleri ve Tonlama: & 1 \\
\cline { 2 - 3 } & $>$ Pürüzsüzlük: & 2 \\
\cline { 2 - 3 } & $>$ Hiz: & 7 \\
\hline Okuduğunu Anlama & & 3 \\
\hline
\end{tabular}

Akyol, Rasinski vd. (2014)'e göre kelime tanıma yüzdesi öğretimsel okuma düzeyinde yüzde 92-98 aralığında, bağımsız okuma düzeyi doğruluk oranı ise yüzde 99100 aralığını işaret etmektedir. Güneş (2013) tarafından çok sayıda uygulamalardan yola çıkılarak okuma hızı ile ilgili bazı ölçütler geliştirilmiştir. Bu ölçütlere göre; 1.sınıf 
öğrencilerinin yıl sonuna kadar 60 kelime, 2.sınıf öğrencilerinin dakikada 80 kelime, 3.sınıf öğrencilerinin dakikada 100 kelime, 4.sınıf öğrencilerinin dakikada 120 kelime ve 5.sınıf öğrencilerinin dakikada 140 kelime okuması öngörülmektedir. Eğitim-öğretim yılı başında veya bir çalışmanın ön uygulaması aşmasında öğrenci prozodi rubriğinin alt boyutları toplamından 8 veya altında puan almışsa bu kaygı verici bir durum değildir. Ancak eğitim-öğretim yılı sonunda veya bir çalışmanın son uygulaması aşamasında öğrenci 8 veya altında puan aldıysa bu durum kaygı vericidir ve öğrenci ek uygulamalara veya okuma prozodisinin geliştirilmesi için öğretime ihtiyaç duyduğunu göstermektedir (Akyol, Rasinski vd., 2014). Yine okuduğunu anlatma yoluyla okuduğunu anlamayı değerlendirme rubriğine göre, rubrikten üç veya altında puan alan öğrencinin metni anlamadığını ve metinle ilgili bilgileri hatırlamadığını göstermektedir. Eğitim-öğretim yılı sonu veya yapılan uygulama sonucunda öğrencinin 4-6 aralığında bir puan alması beklenir (Akyol, Rasinski vd., 2014).

Tablo 5'te belirtilen okuma akıcılığı ön uygulama puanlarına göre öğrencinin kelime tanıma yüzdesi 79 olarak bulunmuştur. Bu yüzde oranı öğrencinin öğretimsel okuma düzeyinin altında olduğunu göstermektedir. Öğrencinin bir dakikada okuduğu kelime sayısı ise 19 olarak bulunmuştur. Bu sayı sınıf düzeyine göre okuma öngörülen ölçütlerle kıyaslandığında bu ölçütlerin oldukça altındadır. Çünkü bu ölçütlere göre 5.sınıf düzeyinde bir öğrencinin 1 dakikada ortalama 80-140 arası kelime okumas1 gerekir. Öğrenci okuma prozodisi rubriğinin alt boyutlara göre toplamda 7 puan almıştır. Bu aşamanın ön uygulama olması nedeniyle aldığ 1 bu toplam puan okuma prozodisi açısından kayg1 verici değildir. Okuduğunu anlama rubriğine göre öğrenci 3 puan almıştır. Bu aşamanın ön uygulama olması nedeniyle öğrencinin okuduğunu anlamada aldığı puan normal karşılanmaktadır.

\section{Son uygulamaya ilişkin bulgular}

Yapılan akıcı okuma çalışmaları sonrasında öğrencinin akıcı okuma düzeyinin nerden nereye geldiğini tespit amacıyla öğrenci iki farklı metin okutulmuştur. Bu metinlerden ilki ön uygulama aşamasında okutulan 4.sınıf düzeyinde, 121 kelimeden oluşan "Heyecan Doruklarda" metni. İkincisi ise 5.sınıf düzeyinde, 165 kelimeden oluşan "Ebru Sanatı" adlı metin. Öğrenci 121 kelimeden oluşan "Heyecan Doruklarda" adlı metni 4.28 dakikada okuyabilmiş, 165 kelimeden oluşan "Ebru Sanatı" adlı metni ise 5.53 dakikada okuyabilmiştir. Bu veriler belirlenen ölçek ve rubriklere göre analiz edilmiş ve sonuçları aşağıda açıklamıştır.

Tablo 6. "Heyecan Doruklarda" Metnine Göre Son Ölçüm İçin Ortam ve Seslendirme Ölçeği Puanlar1

\begin{tabular}{|c|c|c|c|c|}
\hline \multirow[t]{2}{*}{ Yapılan Hata } & \multicolumn{2}{|c|}{ Sonuç } & \multirow[b]{2}{*}{ Açıklama } & Ölçüm Kriterleri \\
\hline & $\begin{array}{l}\text { Ortam } \\
\text { Ölçeği }\end{array}$ & $\begin{array}{l}\text { Seslendirme } \\
\text { Ölçeği }\end{array}$ & & \multirow{3}{*}{$\begin{array}{l}\text { Ortam Ölçeği Puanları } \\
0=\text { Hiç Okumadı } \\
1=\text { Kelimeyi Öğretmen } \\
\text { Verdi } \\
2=\text { Aynı } \\
\text { Kelimeleri/Yapıları }\end{array}$} \\
\hline $\begin{array}{ll}\text { Y } & \text { çıkarlar } \\
\text { D } & \text { çıktılar }\end{array}$ & $3 / 5$ & $6 / 8$ & $\begin{array}{l}\text { Önce "çıkar" } \\
\text { dedi sonra } \\
\text { "çıarlar" diye } \\
\text { okudu }\end{array}$ & \\
\hline $\begin{array}{ll}\text { Y } & \text { uçaklar } \\
\text { D } & \text { uçurtma }\end{array}$ & $2 / 5$ & $2 / 7$ & $\begin{array}{l}\text { "uçaklar" diye } \\
\text { okudu } \\
\text { öğretmen }\end{array}$ & \\
\hline
\end{tabular}




\begin{tabular}{|c|c|c|c|c|c|}
\hline & & & & düzeltti. & \multirow{5}{*}{$\begin{array}{l}\text { İçermedi } \\
3=\text { Aynı } \\
\text { Kelimeleri/Yapıları } \\
\text { İçerdi } \\
4=\text { Kendi Koyduğu } \\
\text { Kelimeler Yazarla Aynı } \\
\text { İfadede } \\
5=\text { Kendini Düzeltti }\end{array}$} \\
\hline Y & yaklaşmış & $1 / 5$ & $7 / 9$ & & \\
\hline $\begin{array}{l}Y \\
\mathrm{D}\end{array}$ & $\begin{array}{l}\text { gökyüzünde } \\
\text { gökyüzüne }\end{array}$ & $4 / 5$ & $8 / 9$ & & \\
\hline $\mathrm{Y}$ & at1yordu & \multirow[b]{2}{*}{$4 / 5$} & \multirow[b]{2}{*}{$6 / 6$} & "atıyordu" & \\
\hline D & at1yor & & & $\begin{array}{l}\text { olarak okudu } \\
\text { öğretmen } \\
\text { düzeltti. }\end{array}$ & \\
\hline $\begin{array}{l}\mathrm{Y} \\
\mathrm{D}\end{array}$ & $\begin{array}{l}\text { aramışt1 } \\
\text { artmışt1 }\end{array}$ & $1 / 5$ & $7 / 8$ & $\begin{array}{l}\text { "aramıştı" } \\
\text { olarak okudu } \\
\text { öğretmen } \\
\text { düzeltti }\end{array}$ & \multirow{6}{*}{$\begin{array}{l}\text { Seslendirme Ölçeği } \\
\text { Puanları } \\
0=\text { Kendi Koyduğu } \\
\text { Kelimeyle Harf } \\
\text { Benzerliği Yok } \\
\text { 1 = Kendi Koyduğu } \\
\text { Kelimeyle 1 Harf } \\
\text { Benzerliği Var } \\
2 \text { = Kendi Koyduğu } \\
\text { Kelimeyle } 2 \text { Harf } \\
\text { Benzerliği Var } \\
\text { N =Kendi Koyduğu } \\
\text { Kelimeyle N Harf } \\
\text { Benzerliği Var }\end{array}$} \\
\hline $\begin{array}{l}\mathrm{Y} \\
\mathrm{D}\end{array}$ & $\begin{array}{l}\text { ulaştılar } \\
\text { ulaşamayan }\end{array}$ & $2 / 5$ & $4 / 10$ & & \\
\hline $\begin{array}{l}\text { Y } \\
\mathrm{D}\end{array}$ & $\begin{array}{l}\text { birbirlerine } \\
\text { birbirine }\end{array}$ & $4 / 5$ & $9 / 9$ & & \\
\hline $\begin{array}{l}\mathrm{Y} \\
\mathrm{D}\end{array}$ & $\begin{array}{l}\text { bitkine } \\
\text { bitimine }\end{array}$ & $1 / 5$ & $6 / 8$ & & \\
\hline $\begin{array}{l}\mathrm{Y} \\
\mathrm{D}\end{array}$ & $\begin{array}{l}\text { izlerinin } \\
\text { izleyenlerin }\end{array}$ & $1 / 5$ & $6 / 12$ & & \\
\hline $\begin{array}{l}\mathrm{Y} \\
\mathrm{D}\end{array}$ & $\begin{array}{l}\text { aliyordu } \\
\text { alıciydı }\end{array}$ & $3 / 5$ & $4 / 8$ & $\begin{array}{l}\text { "aliyordu" } \\
\text { olarak okudu } \\
\text { öğretmen } \\
\text { düzeltti. }\end{array}$ & \\
\hline $\begin{array}{l}\mathrm{Y} \\
\mathrm{D}\end{array}$ & $\begin{array}{l}\text { Ali’yi } \\
\text { Ali'yi de }\end{array}$ & $5 / 5$ & $7 / 7$ & $\begin{array}{l}\text { “Ali’yi” diye } \\
\text { okudu bekleyip } \\
\text { "Ali’yi de” diye } \\
\text { okuyarak } \\
\text { kendini düzeltti }\end{array}$ & \\
\hline $\begin{array}{l}\mathrm{Y} \\
\mathrm{D}\end{array}$ & $\begin{array}{l}\text { ona } \\
\text { onu }\end{array}$ & $3 / 5$ & $2 / 3$ & & \\
\hline \multicolumn{2}{|c|}{ Toplam } & $34 / 65$ & $74 / 104$ & \multirow{2}{*}{\multicolumn{2}{|c|}{$\begin{array}{l}*=\% 90 \text { 'ın altında olduğu için endişe } \\
\text { düzeyi. }\end{array}$}} \\
\hline Yüz & & 52 & 71 & & \\
\hline
\end{tabular}

Tablo 7. "Heyecan Doruklarda" Metnine Göre Son Ölçüm İçin Anlama Ölçeği Puanları

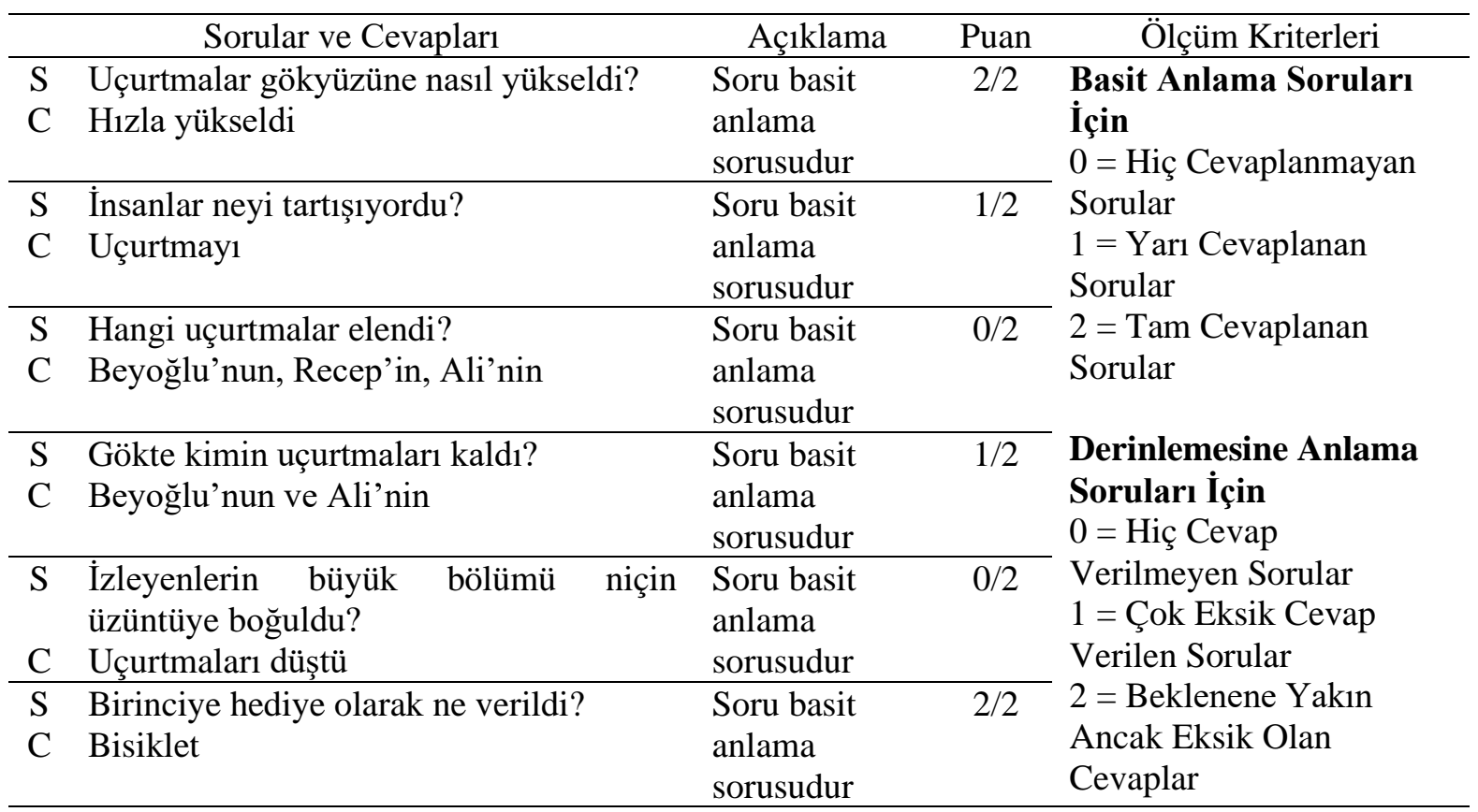




\section{Toplam}

$3=$ Tam ve Etkili

$6 / 12$ Cevaplar

Yüzde

$50 *=\% 50$ olduğu için endişe düzeyi

Ölçüm sonuçlarına göre kelime tanıma düzeyi açısından 99+(99-100) aralığ1 serbest düzey, yüzde 91-98 aralığı öğretim düzeyi ve yüzde 90-altı aralığ1 ise endişe düzeyidir. Anlama düzeyi açısından ise 90+(90-100) aralığ1 serbest düzey, yüzde 75(5189) aralığ 1 serbest düzey ve yüzde 50-(50 ve altı) aralığ 1 endişe düzeyidir (Ekwall ve Shanker, 1988'den Aktaran Akyol, 2003). Öğrenci 4.28 dakikada 121 kelimeden oluşan metnin tamamını okumuştur. Okuma esnasında 13 hata yapmıştır. Metnin devamında öğrenciye metinle ilgili 6 soru yöneltilmiştir. Öğrencinin uygulama sonrası okuduğunu anlama becerisindeki gelişimi belirleme nedeniyle ön uygulamaya göre son uygulamada öğrenciye daha fazla soru sorulmuştur. Öğrenci bu sorulardan 2 tanesine tam cevap, 2 tanesine yarım cevap ve 2 tanesine de yanlış vermiştir. Tablo 6'daki bulgulara göre öğrenci ortam ölçeğinden 52 ve seslendirme ölçeğinden 71 puan almıştır. Bu sonuçlar yukarıdaki verilere göre öğrencinin kelime tanıma düzeyi açısından endişe düzeyinde olduğunu göstermektedir. Tablo 6'daki bulgulara göre ise öğrenci anlama ölçeğinden 50 puan almıştır. Yine yukarıdaki verilerle karşılaştırıldığında öğrencinin anlama düzeyi açısından da endişe düzeyinde olduğu görülmektedir.

Öğrencinin son uygulama sonrası okuma akıcılığını değerlendirmek için okuduğu metinde kelime tanıma yüzdesine, okuma hızına, okuma prozodisine ve okuduğunu anlama durumuna bakılmıştır. Bunun için okuma yüzdesi ve hızı hesaplamaları yapılmış, okuma prozodisi ve okuduğunu anlama rubriğine göre değerlendirmeler yapılıp, sonuçları Tablo 8'de açıklanmıştır.

Tablo 8. Okuma Akıcılığı Son Uygulama Puanları

\begin{tabular}{llc}
\hline Kelime Tanıma & \multicolumn{1}{c}{ Doğru Okunan Kelime Sayısı } & $\% 88$ \\
\cline { 2 - 3 } & Okunan Toplam Kelime Sayısı & \\
\hline Okuma Hızı & Dakikada Okunan Doğru Kelime Sayısı & 40 \\
\hline \multirow{3}{*}{ Prozodi } & $>$ İfade ve Ses Düzeyi: & 3 \\
\cline { 2 - 3 } & $>$ Anlam Üniteleri ve Tonlama: & 2 \\
\cline { 2 - 3 } & $>$ Pürüzsüzlük: & 2 \\
\cline { 2 - 3 } & $>$ Hı: & 10 \\
\hline Okuduğunu Anlama & & 4 \\
\cline { 2 - 3 } & &
\end{tabular}

Akyol, Rasinski vd. (2014)'e göre kelime tanıma yüzdesi öğretimsel okuma düzeyinde yüzde 92-98 aralığında, bağımsız okuma düzeyi doğruluk oranı ise yüzde 99100 aralığını işaret etmektedir. Güneş (2013) tarafından çok sayıda uygulamalardan yola çıkılarak okuma hızı ile ilgili bazı ölçütler geliştirilmiştir. Bu ölçütlere göre; 1.sınıf öğrencilerinin yıl sonuna kadar 60 kelime, 2.sınıf öğrencilerinin dakikada 80 kelime, 3.sınıf öğrencilerinin dakikada 100 kelime, 4.sınıf öğrencilerinin dakikada 120 kelime ve 5.sınıf öğrencilerinin dakikada 140 kelime okuması öngörülmektedir. Eğitim-öğretim yılı başında veya bir çalışmanın ön uygulaması aşmasında öğrenci prozodi rubriğinin alt boyutları toplamından 8 veya altında puan almışsa bu kaygı verici bir durum değildir. 
Ancak eğitim-öğretim yılı sonunda veya bir çalışmanın son uygulaması aşamasında öğrenci 8 veya altında puan aldıysa bu durum kaygı vericidir ve öğrenci ek uygulamalara veya okuma prozodisinin geliştirilmesi için öğretime ihtiyaç duyduğunu göstermektedir (Akyol, Rasinski vd., 2014). Yine okuduğunu anlatma yoluyla okuduğunu anlamayı değerlendirme rubriğine göre, rubrikten üç veya altında puan alan öğrencinin metni anlamadığını ve metinle ilgili bilgileri hatırlamadığını göstermektedir. Eğitim-öğretim yılı sonu veya yapılan uygulama sonucunda öğrencinin 4-6 aralığında bir puan alması beklenir (Akyol, Rasinski vd., 2014).

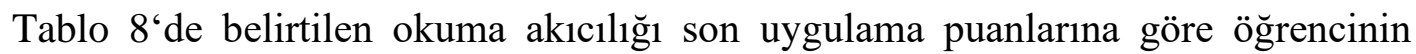
kelime tanıma yüzdesi 88 olarak bulunmuştur. Bu yüzde oranı öğrencinin öğretimsel okuma düzeyinin altında olduğunu göstermektedir. Öğrencinin bir dakikada okuduğu kelime sayısı ise 40 olarak bulunmuştur. Bu sayı sınıf düzeyine göre okuma öngörülen ölçütlerle kıyaslandığında bu ölçütlerin oldukça altındadır. Çünkü bu ölçütlere göre 5.sınıf düzeyinde bir öğrencinin 1 dakikada ortalama 80-140 arası kelime okuması gerekir. Öğrenci okuma prozodisi rubriğinin alt boyutlara göre toplamda 10 puan almıştır. Öğrencinin aldığı bu toplam puan okuma prozodisi açısından uygundur. Okuduğunu anlama rubriğine göre öğrenci 4 puan almıştır. Öğrencinin okuduğunu anlamadan aldığ 1 puan belirlenen ölçütlere göre uygundur.

Son uygulama aşmasında okutulan bir diğer metin ise 5.sınıf düzeyinde "Ebru Sanatı" adlı metindir. Bu metin 165 kelimeden oluşmaktadır. Öğrenci bu metni 5.53 dakikada tamamını okumuştur. $\mathrm{Bu}$ veriler belirlenen ölçek ve rubriklere göre analiz edilmiş ve sonuçları aşağıda açıklamıştır.

Tablo 9. "Ebru Sanatı” Metnine Göre Son Ölçüm İçin Ortam ve Seslendirme Ölçeği Puanları

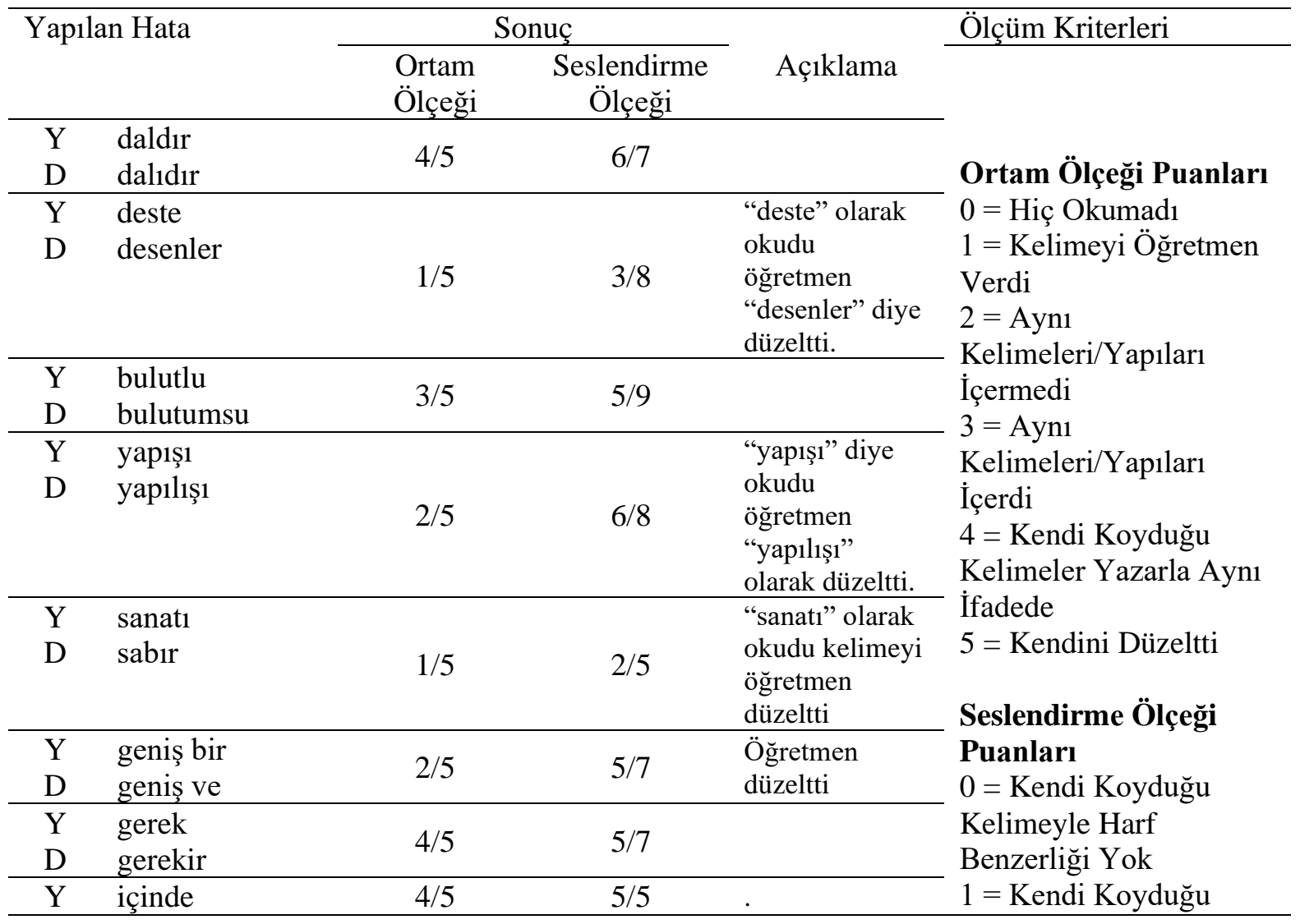




\begin{tabular}{|c|c|c|c|c|c|}
\hline $\mathrm{D}$ & içine & & & & \multirow{26}{*}{$\begin{array}{l}\text { Kelimeyle } 1 \text { Harf } \\
\text { Benzerliği Var } \\
2=\text { Kendi Koyduğu } \\
\text { Kelimeyle } 2 \text { Harf } \\
\text { Benzerliği Var } \\
\text { N =Kendi Koyduğu } \\
\text { Kelimeyle N Harf } \\
\text { Benzerliği Var }\end{array}$} \\
\hline $\mathrm{Y}$ & kondu & \multirow{4}{*}{$2 / 5$} & \multirow{4}{*}{$3 / 5$} & "kondu" diye & \\
\hline \multirow[t]{3}{*}{ D } & konur & & & okudu & \\
\hline & & & & öğretmen & \\
\hline & & & & "konur” olarak & \\
\hline \multirow{4}{*}{$\begin{array}{l}Y \\
D\end{array}$} & firsatlarda & \multirow{4}{*}{$1 / 5$} & \multirow{4}{*}{$7 / 11$} & "firsatlarda" & \\
\hline & fincanlarda & & & olarak okudu & \\
\hline & & & & kelimeyi & \\
\hline & & & & $\begin{array}{l}\text { öğretmen } \\
\text { düzeltti }\end{array}$ & \\
\hline $\mathrm{Y}$ & üzerinde & \multirow{2}{*}{$4 / 5$} & \multirow{2}{*}{$8 / 8$} & & \\
\hline D & üzerine & & & & \\
\hline \multirow{4}{*}{$\begin{array}{l}\mathrm{Y} \\
\mathrm{D}\end{array}$} & birlik & \multirow{4}{*}{$1 / 5$} & \multirow{4}{*}{$5 / 12$} & "birlik" olarak & \\
\hline & birikintiler & & & okudu kelimeyi & \\
\hline & & & & öğretmen & \\
\hline & & & & düzeltti & \\
\hline $\mathrm{Y}$ & şakırtıcı & \multirow{2}{*}{$3 / 5$} & \multirow{2}{*}{$8 / 9$} & & \\
\hline D & şaşırtıc1 & & & & \\
\hline \multirow{4}{*}{$\begin{array}{l}\text { Y } \\
D\end{array}$} & & \multirow{4}{*}{$1 / 5$} & \multirow{4}{*}{$6 / 8$} & "desler" olarak & \\
\hline & & & & okudu & \\
\hline & desenler & & & kelimeyi & \\
\hline & & & & $\begin{array}{l}\text { öğretmen } \\
\text { diizeltti }\end{array}$ & \\
\hline & dersler & \multirow{5}{*}{$1 / 5$} & \multirow{5}{*}{$6 / 8$} & "desler" olarak & \\
\hline & desenler & & & & \\
\hline & & & & kelimeyi & \\
\hline & & & & öğretmen & \\
\hline & & & & düzeltti & \\
\hline \multicolumn{2}{|c|}{ Toplam } & $34 / 75$ & $80 / 117$ & \multirow{2}{*}{\multicolumn{2}{|c|}{$\begin{array}{l}*=\% 90 \text { 'ın altında olduğu için endişe } \\
\text { düzeyi. }\end{array}$}} \\
\hline \multicolumn{2}{|c|}{ Yüzde } & 45 & 68 & & \\
\hline
\end{tabular}

Tablo 10. "Ebru Sanatı" Metnine Göre Son Ölçüm İçin Anlama Ölçeği Puanları

\begin{tabular}{|c|c|c|c|c|}
\hline & Sorular ve Cevapları & Açıklama & Puan & Ölçüm Kriterleri \\
\hline $\begin{array}{l}\mathrm{S} \\
\mathrm{C}\end{array}$ & $\begin{array}{l}\text { Ebruya nerelerde rastlanır? } \\
\text { Sanatta }\end{array}$ & $\begin{array}{l}\text { Soru basit } \\
\text { anlama } \\
\text { sorusudur. }\end{array}$ & $0 / 2$ & \multirow{6}{*}{$\begin{array}{l}\text { Basit Anlama Soruları } \\
\text { İçin } \\
0 \text { = Hiç Cevaplanmayan } \\
\text { Sorular } \\
\text { 1 = Yarı Cevaplanan } \\
\text { Sorular } \\
2 \text { = Tam Cevaplanan } \\
\text { Sorular } \\
\text { Derinlemesine Anlama } \\
\text { Soruları İçin } \\
0 \text { = Hiç Cevap } \\
\text { Verilmeyen Sorular } \\
\text { 1 = Çok Eksik Cevap } \\
\text { Verilen Sorular } \\
\text { 2 = Beklenene Yakın } \\
\text { Ancak Eksik Olan } \\
\text { Cevaplar } \\
3 \text { = Tam ve Etkili } \\
\text { Cevaplar }\end{array}$} \\
\hline$S$ & $\begin{array}{l}\text { Ebru sanatında renkler ve desenler } \\
\text { nas1l bir görüntü oluşturur? } \\
\text { Dikdörtgen }\end{array}$ & $\begin{array}{l}\text { Soru basit } \\
\text { anlama } \\
\text { sorusudur. }\end{array}$ & $0 / 2$ & \\
\hline $\begin{array}{l}\mathrm{S} \\
\mathrm{C}\end{array}$ & $\begin{array}{l}\text { Ebrunun yapilışı ne ister? } \\
\text { Giysi ve süsleme ister }\end{array}$ & $\begin{array}{l}\text { Soru basit } \\
\text { anlama } \\
\text { sorusudur. }\end{array}$ & $0 / 2$ & \\
\hline $\begin{array}{l}\mathrm{S} \\
\mathrm{C}\end{array}$ & $\begin{array}{l}\text { Ebru nasıl yapılır? Anlatınız. } \\
\text { Masalar, örtü ve perde }\end{array}$ & $\begin{array}{l}\text { Soru basit } \\
\text { anlama } \\
\text { sorusudur. }\end{array}$ & $0 / 2$ & \\
\hline $\mathrm{C}$ & $\begin{array}{l}\text { Ebru desenlerini } \\
\text { görebiliriz? } \\
\text { Her yerde }\end{array}$ & $\begin{array}{l}\text { Soru basit } \\
\text { anlama } \\
\text { sorusudur. }\end{array}$ & $1 / 2$ & \\
\hline \multicolumn{2}{|l|}{ Toplam } & & $1 / 10$ & \\
\hline
\end{tabular}


Ölçüm sonuçlarına göre kelime tanıma düzeyi açısından 99+(99-100) aralığı serbest düzey, yüzde 91-98 aralığı öğretim düzeyi ve yüzde 90-altı aralığı ise endişe düzeyidir. Anlama düzeyi açısından ise $90+(90-100)$ aralığı serbest düzey, yüzde 75(5189) aralığ1 serbest düzey ve yüzde 50-(50 ve altı) aralığı endişe düzeyidir (Ekwall ve Shanker, 1988'den Aktaran Akyol, 2003). Öğrenci 5.53 dakikada 165 kelimeden oluşan metnin tamamını okumuştur. Okuma esnasında 15 hata yapmıştır. Metnin devamında öğrenciye metinle ilgili 5 soru yöneltilmiştir. Öğrenci bu sorulardan 4 tanesini yanlış cevaplamış, 2 tanesine de yarım cevap vermiştir. Tablo 9'daki bulgulara göre öğrenci ortam ölçeğinden 45 ve seslendirme ölçeğinden 68 puan almıştır. Bu sonuçlar yukarıdaki verileri göre öğrencinin kelime tanıma düzeyi açısından endişe düzeyinde olduğunu göstermektedir. Tablo 10'daki bulgulara göre ise öğrenci anlama ölçeğinden 10 puan almıştır. Yine yukarıdaki verilerle karşılaştırıldığında öğrencinin anlama düzeyi açısından da endişe düzeyinde olduğu görülmektedir.

Öğrencinin son uygulama sonrası okuma akıcılığını değerlendirmek için okuduğu metinde (Ebru Sanatı metni) kelime tanıma yüzdesine, okuma hızına, okuma prozodisine ve okuduğunu anlama durumuna bakılmıştır. Bunun için okuma yüzdesi ve hızı hesaplamaları yapılmış, okuma prozodisi ve okuduğunu anlama rubriğine göre değerlendirmeler yapılıp, sonuçları Tablo 11'de açıklanmıştır.

Tablo 11. Okuma Akıcılığı Son Uygulama Puanları (Ebru Sanatı Adlı Metin)

\begin{tabular}{llc}
\hline \multirow{2}{*}{ Kelime Tanıma } & \multicolumn{1}{c}{ Doğru Okunan Kelime Sayısı } & $\% 93$ \\
\cline { 2 - 3 } & Okunan Toplam Kelime Sayısı & \\
\hline Okuma Hızı & Dakikada Okunan Doğru Kelime Sayısı & 40 \\
\hline \multirow{3}{*}{ Prozodi } & $>$ İfade ve Ses Düzeyi: & 3 \\
\cline { 2 - 3 } & $>$ Anlam Üniteleri ve Tonlama: & 2 \\
\cline { 2 - 3 } & $>$ Pürüzsüzlük: & 2 \\
\cline { 2 - 3 } & $>$ Hiz: & 10 \\
\hline Okuduğunu Anlama & $>$ Toplam Puan: & 4 \\
\hline
\end{tabular}

Akyol, Rasinski vd. (2014)'e göre kelime tanıma yüzdesi öğretimsel okuma düzeyinde yüzde 92-98 aralığında, bağımsız okuma düzeyi doğruluk oranı ise yüzde 99100 aralığını işaret etmektedir. Güneş (2013) tarafindan çok sayıda uygulamalardan yola çıkılarak okuma hızı ile ilgili bazı ölçütler geliştirilmiştir. Bu ölçütlere göre; 1.sınıf öğrencilerinin yıl sonuna kadar 60 kelime, 2.sınıf öğrencilerinin dakikada 80 kelime, 3.sınıf öğrencilerinin dakikada 100 kelime, 4.sınıf öğrencilerinin dakikada 120 kelime ve 5.sınıf öğrencilerinin dakikada 140 kelime okuması öngörülmektedir. Eğitim-öğretim yılı başında veya bir çalışmanın ön uygulaması aşmasında öğrenci prozodi rubriğinin alt boyutları toplamından 8 veya altında puan almışsa bu kaygı verici bir durum değildir. Ancak eğitim-öğretim yılı sonunda veya bir çalışmanın son uygulaması aşamasında öğrenci 8 veya altında puan aldıysa bu durum kaygı vericidir ve öğrenci ek uygulamalara veya okuma prozodisinin geliştirilmesi için öğretime ihtiyaç duyduğunu göstermektedir 
(Akyol, Rasinski vd., 2014). Yine okuduğunu anlatma yoluyla okuduğunu anlamayı değerlendirme rubriğine göre, rubrikten üç veya altında puan alan öğrencinin metni anlamadığını ve metinle ilgili bilgileri hatırlamadığını göstermektedir. Eğitim-öğretim yılı sonu veya yapılan uygulama sonucunda öğrencinin 4-6 aralığında bir puan alması beklenir (Akyol, Rasinski vd., 2014).

Tablo 11'de belirtilen okuma akıcılığı son uygulama (Ebru Sanatı Metni) puanlarına göre öğrencinin kelime tanıma yüzdesi 93 olarak bulunmuştur. Bu yüzde oranı öğrencinin öğretimsel okuma düzeyinde göstermektedir. Öğrencinin bir dakikada okuduğu kelime sayısı ise 40 olarak bulunmuştur. Bu sayı sınıf düzeyine göre okuma öngörülen ölçütlerle kıyaslandığında bu ölçütlerin oldukça altındadır. Çünkü bu ölçütlere göre 5.sınıf düzeyinde bir öğrencinin 1 dakikada ortalama 80-140 arası kelime okuması gerekir. Öğrenci okuma prozodisi rubriğinin alt boyutlara göre toplamda 10 puan almıştır. Öğrencinin aldığı bu toplam puan okuma prozodisi açısından uygundur. Okuduğunu anlama rubriğine göre öğrenci 4 puan almıştır. Öğrencinin okuduğunu anlamadan aldığ puan belirlenen ölçütlere göre uygundur.

\section{Tartışma}

Birden fazla akıcı okuma yöntem ve tekniğine dayalı olarak yapılan okuma çalışmalarında öğrenci düzey olarak endişe düzeyinde kalsa bile öğrencinin okuma becerilerinin gelişiminde matematiksel olarak bir artışın olduğu görülmektedir. Ülkemizde akıcı okuma problemlerinin giderilmesine yönelik yapılan benzer çalışmalar (Akyol ve Sever, 2019; Çayır ve Balcı, 2017) incelendiğinde sonuçlarının bu araştırmanın sonuçlarında olduğu gibi öğrencinin okuma düzeyinde bir ilerletme sağlamayıp ancak okuma becerilerinde matematiksel olarak bir artış sağladığı görülmektedir. Sağlam, Baş ve Akyol (2020); Erbasan ve Sağlam (2020); Kuruoğlu ve Şen (2019); Kanık Uysal ve Akyol (2019); Karasakaloğlu ve Saraçlı Çelik (2018); Akyol ve Ketenoğlu Kayabaşı (2018); Sözen ve Akyol (2018); Akyol ve Kodan (2016); Kardaş İşler ve Şahin (2016); Çeliktürk Sezgin ve Akyol (2015); Yamaç (2014); Duran ve Sezgin (2012)'nin yaptığı çalışmalarda ise akıcı okuma problemi olan öğrencilerin hem okuma düzeylerinde ilerleme olduğu hem de okuma becerilerinde matematiksel anlamda artış olduğu görülmüştür. Bu araştırma ve literatürdeki benzer araştırma sonuçları akıcı okuma sorunu olan öğrencilerle birebir okuma çalışmaları yapıldığında okuma problemlerinde azalma olduğunu ve okuma becerilerinin geliştiğini göstermektedir. Bu sonuçlar akıcı okuma sorunu olan öğrencilere yönelik olarak hazırlanan okuma programlarının etkililiğini göstermektedir.

\section{Sonuç}

Akıcı okuma problemi olan bir öğrencinin, akıcı okuma problemini gidermek amacıyla birden fazla akıcı okuma yöntem ve tekniği (tekrarlı okuma, mırıltılı okuma, kafiyeli okuma, sesli okuma ve görme yelpazesini genişletme) ile 15 ders saati uygulama yapılıp devamında ise öğrencinin okuma hızı, kelime tanıma düzeyi ve okuduğunu anlama becerisinin ölçüldüğü bu araştırma kapsamında elde edilen sonuçlar şöyledir: öğrenci ön uygulamada olduğu gibi son uygulamada da kelime tanıma ve anlama düzeyi açısından endişe düzeyinde kalmıştır. Ancak okuma becerileri gelişiminde matematiksel olarak artış olmuştur. Ön uygulamada 4. sınıf düzeyinde okutulan metinde öğrencinin kelime tanıma 
yüzdesi 79, dakikada okuduğu kelime sayısı 19, prozodi puanı 7 ve okuduğunu anlama puanı ise 3 'tür. Son uygulamada ise ön uygulamada okutulan 4.sınıf düzeyinde metinde öğrencinin kelime tanıma yüzdesi 88 , dakikada okuduğu doğru kelime sayısı 40, prozodi puanı 10 ve okuduğunu anlama puanı 4'e yükselmiştir. Son uygulamada okutulan kendi sınıf düzeyindeki (5.sınıf) metinde ise öğrencinin kelime tanıma yüzdesi 93, dakikada okuduğu doğru kelime sayısı 40, prozodi puanı 10 ve okuduğunu anlama puanı 4'e yükselmiştir.

Yukarıda açıklanan okuma becerilerinin gelişiminin yanında öğrencide görülen bazı okuma hatalarında azalma olduğu gözlemlenmiştir. Öğrenci okuma yaparken kâğıda eğilip uzaklaşma davranışı azalmış ve parmakla takip etmeyi tamamen bırakmıştır. Uzun heceli kelimeleri birkaç kez ilk hecesini okuyup sonra okuyabilme durumu ortadan kalkmıştır. Uzun heceli kelimeleri tek çırpıda okuyabilmektedir. Bu düzelmelere rağmen bazı okuma hataları devam etmektedir. Bunlar; kelimeyi yazıldığı gibi değil de aynı kökte farlı bir kelime olarak okuma, okuyamadığı kelimeyi şeklen ona benzer olan başka bir kelime olarak okuma ve bazı kelimelerin sonundaki ekleri okumamadır.

\section{Uygulama önerileri}

$\mathrm{Bu}$ çalışma belirlenen okuma yöntem ve tekniklerine dayalı olarak 15 ders saati yapılmıştır. Araştırma sonuçlarına dayalı olarak akıcı okuma problemlerinin giderilmesine yönelik yapılacak uygulamaların daha uzun süreli yapılması önerilmektedir. Ayrıca farklı okuma yöntem, teknik ve stratejilerinin denenmesi, kullanılacak okuma materyallerinin çeşitlendirilmesi ve uygulama yapılacak öğrencinin iyi tanınarak öğrencinin problemine dönük uygulamaların yapılması önerilmektedir.

\section{Kaynakça}

Akyol, H. (2011). Türkçe ilkokuma yazma öğretimi (10. baskı). Pegem Akademi Yayıincilik.

Akyol, H., Rasinski, T. V., Yıldırım, K., Ateş, S. \& Çetinkaya, Ç. (2014). Okumayı değerlendirme. Pegem Akademi Yayıncılık.

Akyol, H. \& Sever, E. (2019). Okuma yazma güçlüğü ve bir eylem araştırması: İkinci sınıf örneği. Hacettepe Üniversitesi Ĕ̆itim Fakültesi Dergisi, 34(3), 685-707.

Akyol, H. \& Ketenoğlu Kayabaşı, Z. E. (2018). Okuma güçlüğü yaşayan bir öğrencinin okuma becerilerinin geliştirilmesi: bir eylem araştırması. Eğitim ve Bilim, 43(193), 143-158.

Akyol, H. \& Kodan, H. (2016). Okuma güçlügünün giderilmesine yönelik bir uygulama: akıcı okuma stratejilerinin kullanımı. Ondokuz Mayıs Üniversitesi Eğitim Fakültesi Dergisi, 35(2), 7-21.

Büyüköztürk, Ş., Kılıç Çakmak, E., Akgün, Ö. E., Karadeniz, Ş. \& Demirel, F. (2018). Bilimsel araştırma yöntemleri. Pegem Akademi Yayıncılık

Çayır, A. \& Balcı, E. (2017). Bireyselleştirilmiş okuma programının disleksi riski olan bir ilkokul öğrencisinin okuma becerileri üzerindeki etkisi. Uluslararası Türkçe Edebiyat Kültür Ĕ̈itim Dergisi, 6(1), 455-470. 
Coşkun, C. \& Çeçen, M. (2012). Hızlı ve anlayarak okuma tekniği. BS Yayın Basım Dağıtım

Çeliktürk Sezgin, Z. \& Akyol, H. (2015). Okuma güçlüğü olan dördüncü sınıf öğrencisinin okuma becerilerinin geliştirilmesi. Turkish Journal of Education, 4(2).

Duran, E. \& Bitir, T. (2020). Okuma ĕgitimi (2. baskı). Vizetek Yayıncılık.

Duran, E. \& Sezgin, B. (2012). Rehberli okuma yönteminin akıcı okumaya etkisi. Gazi Eğitim Fakültesi Dergisi, 32(3), 633-655.

Ekwall, E. E., \& Shanker, J. L. (1988). Diagnosis and Remedation of the Disabled Reader. (Third Edition). Allyn and Bacon Inc. (p.403-415).

Erbasan, Ö. \& Sağlam, A. (2020). Okuma güçlüğü olan evde eğitim öğrencisinin okuma becerilerinin geliştirilmesi. Temel Eğitim Dergisi, 2(1), 14-25.

Güneş, F. (2017). Türkçe öğretimi yaklaşımlar ve modeller (5. bask1). Pegem Akademi Yayınc1lik.

Gürkaner, M. \& Güven, S. (2020). Türkiye'de ilkokul düzeyinde akıc1 okuma üzerine yapılan lisansüstü tezlerin incelenmesi. Nevşehir Hacı Bektaş Veli Üniversitesi SBE Dergisi, 10(1), 347-363.

Karasakaloğlu, N. \& Saraçlı Çelik, S. (2018). Rehberle okuma yönteminin ilkokul öğrencilerinin dinlediğini anlama düzeyleriyle akıcı okuma becerilerine. Turkish Studies, 13 (19), 1083-1100.

Kanık Uysal, P. \& Akyol, H. (2019). Okuma güçlüğü ve giderilmesi: Bir eylem araştırmas1. Eğitim ve Bilim, 44(198), 17-35.

Kardaş İşler, N. \& Şahin, A. E. (2016). Bir ilkokul 4. sınıf öğrencisinin okuma bozukluğu ve anlama güçlüğ̈̈: Bir durum çalışması. Ana Dili Eğitimi Dergisi, 4(2), 174-186.

Kuruoğlu, G. \& Şen, N. (2019). Okuma güçlüğü yaşayan ortaokul öğrencilerine uygulanan hızlandırılmış okuma eğitiminin etkisi. Buca Eğitim Fakültesi Dergisi, 47, 36-45.

Özbay, M. (2007). Türkçe özel öğretim yöntemleri II. Öncü Kitap.

Rasinski, T. V. \& Padak, N. (2005). 3-minute reading assessment (Grade 1-4): Word recognation, fluency comprehension. Scholastic Inc.

Sağlam, A., Baş, Ö. \& Akyol, H. (2020). Kelime tekrar tekniğinin üçüncü sınıf özel yetenekli öğrencilerin akıcı okuma düzeylerine etkisi. Journal of History School, 46, 1605-1629.

Samuels, S. Jay. (1997). The method of repeated readings. The Reading Teacher, 50, 376381 .

Sidekli, S. \& Yangın, S. (2005). Okuma güçlüğü olan öğrencilerin okuma becerilerinin geliştirilmesine yönelik bir uygulama. Atatürk Üniversitesi Kazım Karabekir Ĕ̈itim Fakültesi Dergisi, 0 (11), 393-413

Sözen, N. \& Akyol, H. (2018). Rehberli okuma yöntemi: Bir eylem araştırması. Turkish Studies, 13(19), 1633-1658.

Ünalan, Ş. (2006). Türkçe öğretimi. Nobel Yayıncılık.

Yamaç, A. (2014). İlkokul dördüncü sınıf düzeyinde bir öğrencinin sesli okuma akıcılığını artırmaya yönelik bir uygulama. K. Ü. Kastamonu Ĕ̆itim Dergisi, 23 (2),631-644. 
Zutell, J. \& Rasinski, T. V. (1991). Training teachers to attend to their students oral reading fluency. Theory into Practice, 30, 211-217. 